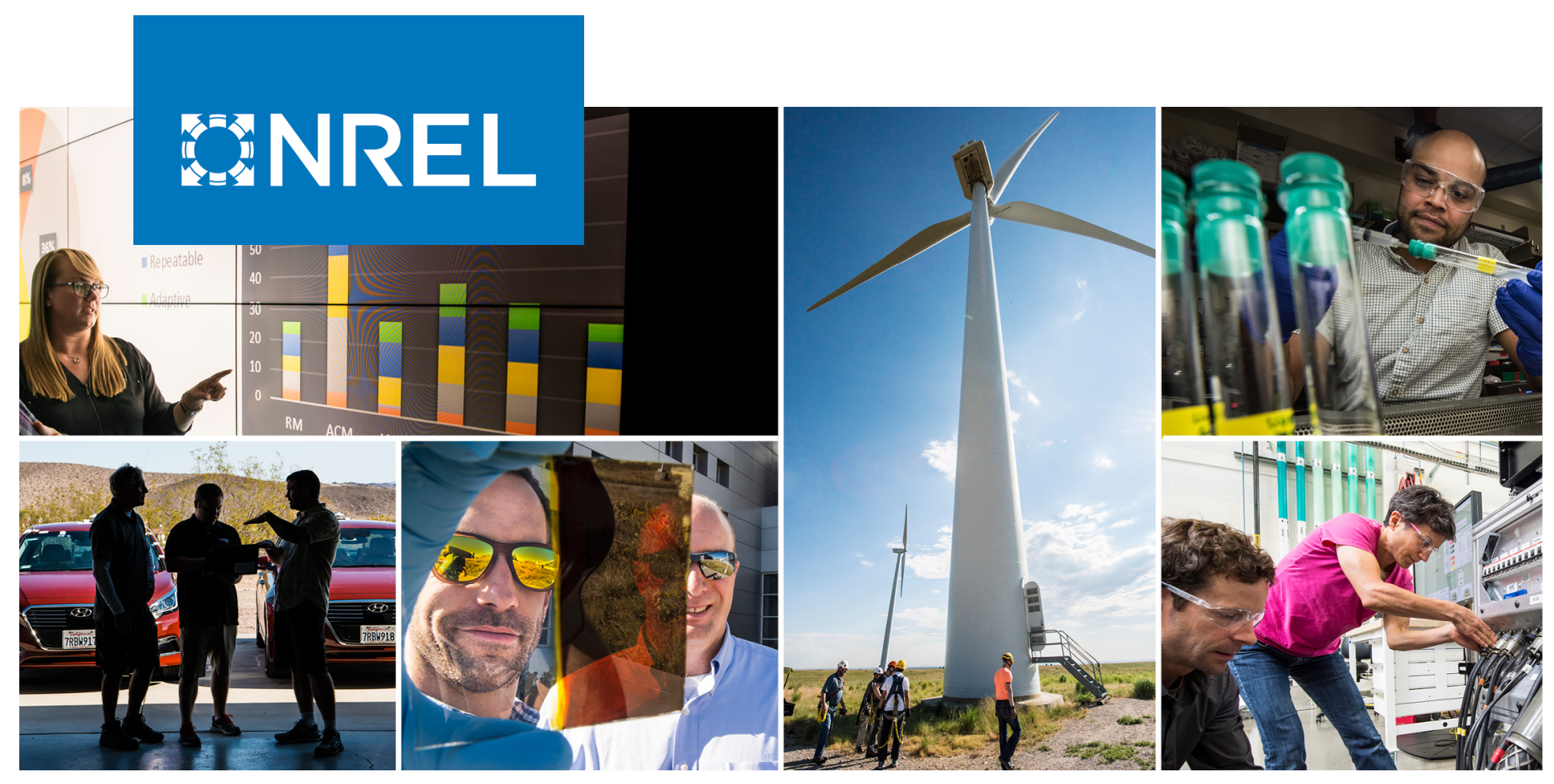

\title{
Fleet-Wide Electrification Impacts Assessment for the Valley Transportation Authority
}

Josh Eichman, Andrew Kotz, Eric Miller, Ken Kelly, and Karen Ficenec

\section{National Renewable Energy Laboratory}

Produced under direction of the California Energy Commission by the National Renewable Energy Laboratory (NREL) under Agreement number FIA-17-01856.

NREL is a national laboratory of the U.S. Department of Energy Office of Energy Efficiency \& Renewable Energy

Operated by the Alliance for Sustainable Energy, LLC

This report is available at no cost from the National Renewable Energy Laboratory (NREL) at www.nrel.gov/publications.
Strategic Partnership Project Report NREL/TP-5400-77547

November 2020 


\section{GHREL}

Fleet-Wide Electrification Impacts Assessment for the Valley Transportation Authority

Josh Eichman, Andrew Kotz, Eric Miller, Ken Kelly, and Karen Ficenec

National Renewable Energy Laboratory

\section{Suggested Citation}

Eichman, Josh, Andrew Kotz, Eric Miller, Ken Kelly, and Karen Ficenec. 2020. Fleet-Wide Electrification Impacts Assessment for the Valley Transportation Authority. Golden, CO: National Renewable Energy Laboratory. NREL/TP-5400-77547.

https://www.nrel.gov/docs/fy21osti/77547.pdf.

NREL is a national laboratory of the U.S. Department of Energy Office of Energy Efficiency \& Renewable Energy Operated by the Alliance for Sustainable Energy, LLC

This report is available at no cost from the National Renewable Energy Laboratory (NREL) at www.nrel.gov/publications.

Contract No. DE-AC36-08GO28308
Strategic Partnership Project Report NREL/TP-5400-77547 November 2020

National Renewable Energy Laboratory 15013 Denver West Parkway Golden, CO 80401 303-275-3000 • www.nrel.gov 


\section{NOTICE}

This work was authored by the National Renewable Energy Laboratory, operated by Alliance for Sustainable Energy, LLC, for the U.S. Department of Energy (DOE) under Contract No. DE-AC36-08G028308. Support for the work was also provided by the California Energy Commission under Agreement FIA-17-01856. The views expressed in the article do not necessarily represent the views of the DOE or the U.S. Government. The U.S. Government retains and the publisher, by accepting the article for publication, acknowledges that the U.S. Government retains a nonexclusive, paid-up, irrevocable, worldwide license to publish or reproduce the published form of this work, or allow others to do so, for U.S. Government purposes.

This report is available at no cost from the National Renewable Energy Laboratory (NREL) at www.nrel.gov/publications.

U.S. Department of Energy (DOE) reports produced after 1991 and a growing number of pre-1991 documents are available free via www.OSTI.gov.

Cover Photos by Dennis Schroeder: (clockwise, left to right) NREL 51934, NREL 45897, NREL 42160, NREL 45891, NREL 48097, NREL 46526.

NREL prints on paper that contains recycled content. 


\section{Acknowledgments}

This work was authored by the National Renewable Energy Laboratory, operated by Alliance for Sustainable Energy, LLC, for the United States (U.S.) Department of Energy (DOE) under Contract No. DE-AC36-08GO28308. Funding was provided by the California Energy Commission as part of their Electric Program Investment Charge in the area of Advanced Vehicle-Grid Integration Research and Demonstration (GFO-16-303). The authors would like to acknowledge the contributions from project partners that helped provide data and critical review to support this report. Partners include Tina Hu, Christian Hosler, and Mike Harrigan from Prospect Silicon Valley, Gary Miskell, Manjit Chopra, Ani Peralairavisundar, Joonie Tolosa, James Wilhelm, and Christina Jaworski from Valley Transportation Authority, Jonathan Norris from Calstart, Paul Lipkin and Rob Calvert from ChargePoint, and Luther Jackson from novaworks. The views expressed in the article do not necessarily represent the views of the DOE or the U.S. Government. 


\section{List of Acronyms}

$\begin{array}{ll}\text { BAU } & \text { business-as-usual } \\ \text { BEB } & \text { battery electric bus } \\ \text { BYD } & \text { Build Your Dreams (automotive company) } \\ \text { CARB } & \text { California Air Resources Board } \\ \text { DCFC } & \text { direct current fast charging } \\ \text { FOM } & \text { fixed operation and maintenance } \\ \text { GPS } & \text { Global Positioning System } \\ \text { ISO } & \text { Independent System Operator (for the electric power system) } \\ \text { LCFS } & \text { Low Carbon Fuel Standard } \\ \text { NAS } & \text { National Academy of Sciences } \\ \text { NPV } & \text { net present value } \\ \text { NREL } & \text { National Renewable Energy Laboratory } \\ \text { PG\&E } & \text { Pacific Gas and Electric } \\ \text { PV } & \text { photovoltaic } \\ \text { RODeO } & \text { Revenue Operation and Device Optimization model } \\ \text { RTO } & \text { Regional Transmission Operator (for the electric power system) } \\ \text { VTA } & \text { Valley Transit Authority } \\ \text { WACC } & \text { weighted average cost of capital }\end{array}$




\section{Executive Summary}

This report explores the long-term electrification opportunities for the Valley Transit Authority's (VTA) transit bus fleet. The potential for transit bus electrification at VTA as well as the economic impacts of partial and complete electrification are explored. We use the Revenue Operation and Device Optimization model to determine the optimal charging, operation and lowest capital and operating cost solution to achieve different levels of electrification to meet their existing routes.

This study finds that, relying on only depot charging, around $70 \%$ of the daily trips ${ }^{1}$ by VTA's transit bus fleet can be replaced with battery electric buses (BEBs) ${ }^{2}$ today. The benefits and drawbacks of five methods for improving the electrification potential beyond that achievable with only depot charging are discussed including (1) increase charger power, (2) purchase of larger vehicle batteries, (3) en-route charging, (4) purchasing additional buses and swapping them to enable the existing routes/blocks ${ }^{1}$ to be met, and (5) route/block redesign. A strategy is developed to enable full fleet electrification by increasing charger power or allowing intraday charging as a proxy for the options mentioned above. This method allows us to develop an understanding of the impacts and trade-offs of full fleet electrification.

Two charging strategies are examined. Immediate charging, when the bus is charged as soon as it arrives at a depot or en-route charging station, and smart charging, which uses a controller to determine the best times to charge to achieve the lowest charging cost, while maintaining the same trip schedules. Smart charging is effective at reducing the peak power consumption, which can be reduced by between $31 \%$ and $65 \%$ compared to immediate charging. This translates directly to lower electricity demand charges and lower costs for possible distribution system upgrades.

The total lifetime net present value (NPV) costs for different scenarios are presented in Figure ES-1. Scenarios are separated into three sections. The first stacked bar on the left is the base case (business-as-usual) where all buses are diesel hybrids, the next four bars include partial and full fleet electrification utilizing only immediate charging, and the last four bars include partial and full fleet electrification utilizing smart charging. The results show that smart charging scenarios are within $\pm 4 \%$ of the lifetime NPV cost of the diesel-hybrid only (business-as-usual) scenario. The scenarios with full fleet electrification (i.e., including intraday charging) are $4 \%$ lower cost and those with partial fleet electrification (i.e., without intraday charging) are $2 \%-3 \%$ higher. However, it is important to note that the intraday charging scenarios do not include any additional costs for the equipment necessary to achieve intraday charging (e.g., additional chargers, larger batteries, new route design). Additionally, it is worth noting that the Low Carbon Fuel Standard (LCFS) credit received for implementing electric buses is essential to achieving these results.

\footnotetext{
${ }^{1}$ Transit system planners package a set of bus stops and scheduled stop times to meet customer needs into routes which are run one or more times each day. These routes are packaged into blocks which are assigned to a given bus. Each day a given bus can complete one or more blocks of work. The set of blocks completed are referred to in this report as trips.

2 This assumes 40-foot BEBs with $350 \mathrm{kWh}$ of usable storage, 60-foot BEBs with $550 \mathrm{kWh}$ of usable storage, and as many $60 \mathrm{~kW}$ chargers as are necessary to meet the charge demand.
} 
Several sensitivities were explored for designing electric bus charging depots including the addition of photovoltaic (PV) panels and battery energy storage. It was found that increasing the amount of PV at the yards can reduce the lifetime NPV costs. Conversely, adding storage does not necessarily reduce the lifetime NPV costs for a significant penetration of BEBs that are already optimally charging. Options to achieve this increased electrification potential are discussed in more detail in the report.

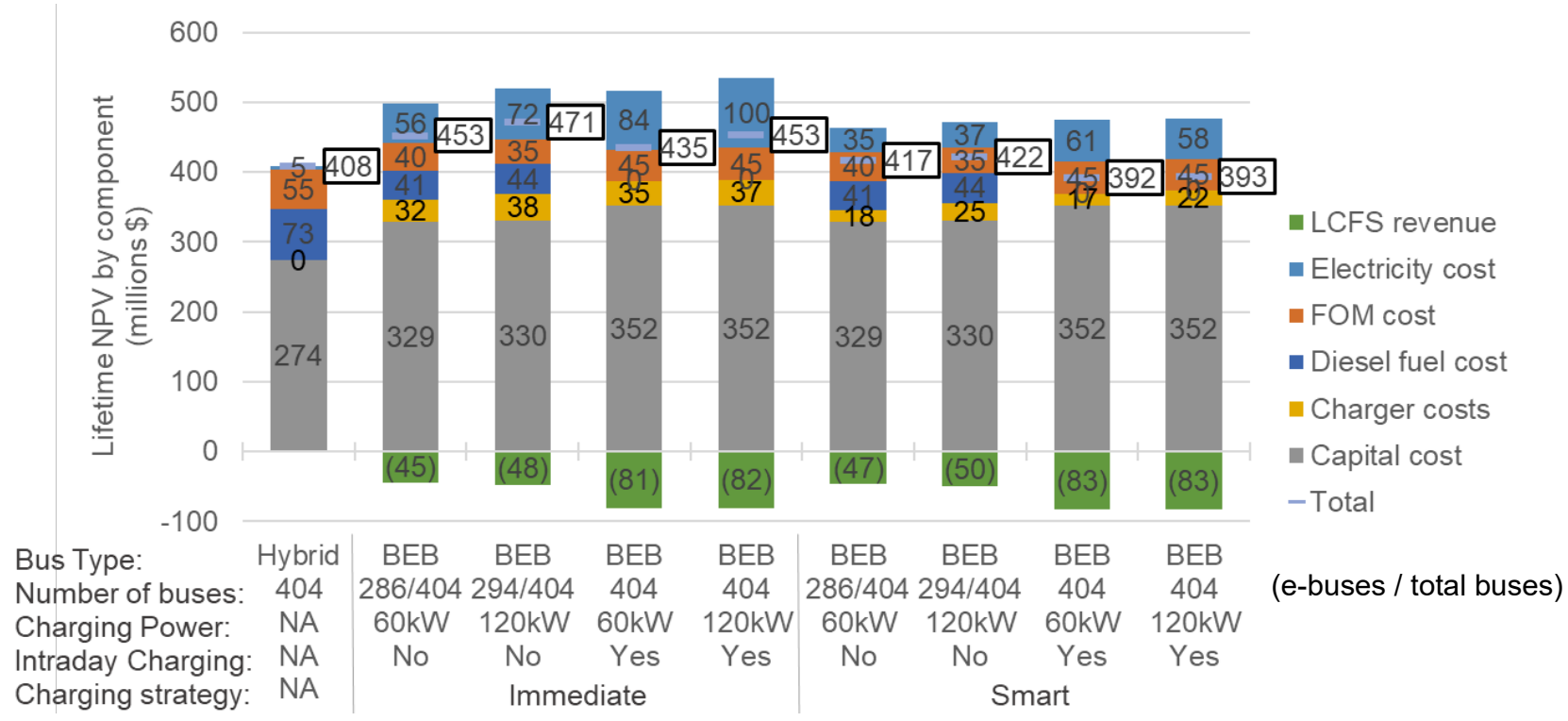

Figure ES-1. Lifetime NPV for near-term implementation of diesel-hybrid only, immediate charging electric buses, and smart charging electric buses

For this report, it is assumed that buses always operate as expected (e.g., there are no breakdowns). Additional costs to further enable electrification (described in this report as intraday charging) and electrical infrastructure upgrades are not included. These items have a wide range of variability from zero dollars to millions of dollars and can affect project economics. The goal of this report is to provide initial estimates for cost and impacts of bus electrification to transit agencies, utilities, and other stakeholders to better characterize costs and opportunities to enabling greater electrification and minimize infrastructure upgrade costs. 


\section{Table of Contents}

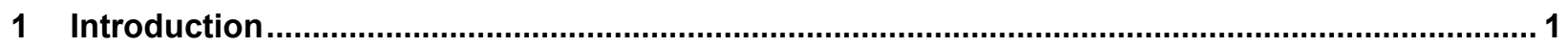

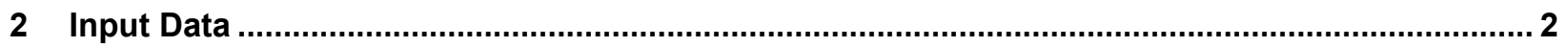

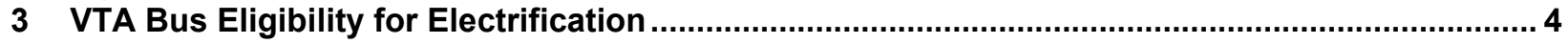

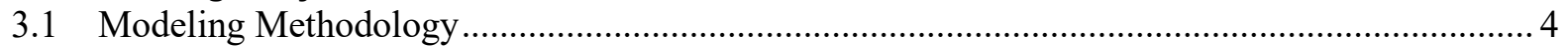

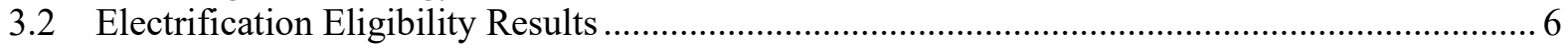

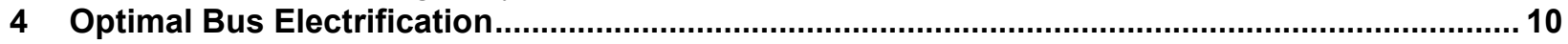

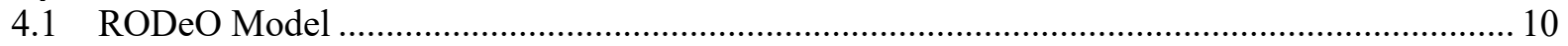

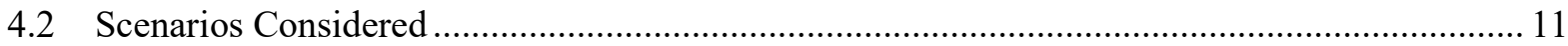

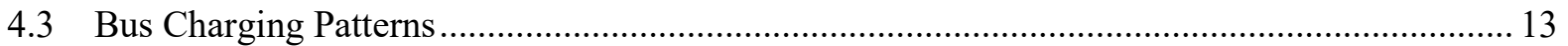

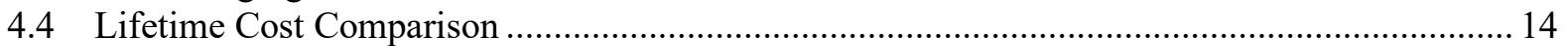

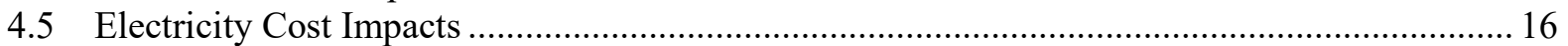

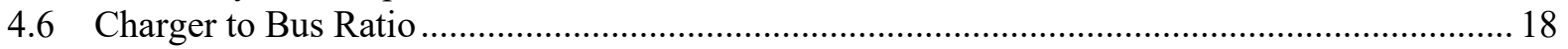

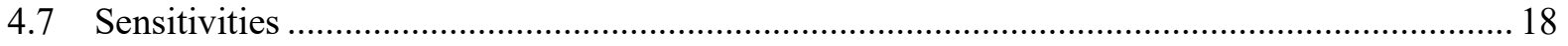

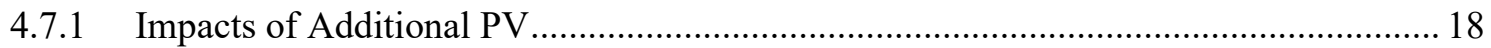

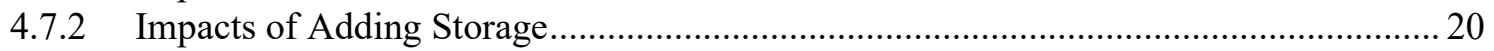

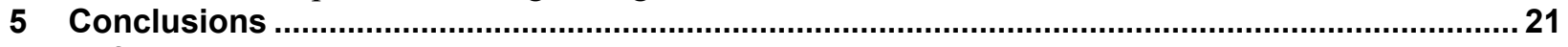

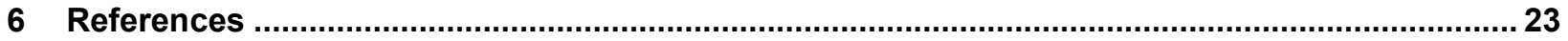




\section{List of Figures}

Figure ES-1. Lifetime NPV for near-term implementation of diesel-hybrid only, immediate charging electric buses, and smart charging electric buses

Figure 1. Example daily trip profiles for 20 random blocks (green = available to charge, red = en-route). 5 Figure 2. Example daily trip profiles for 20 random blocks including current dwell times of 15 min or

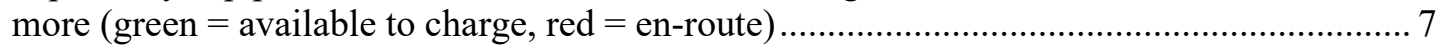

Figure 3. Revenue Operation and Device Optimization modeling framework...................................... 10

Figure 4. Average daily electricity consumption profile for full fleet electrification .............................. 13

Figure 5. Example week of fleet electricity consumption (January 1-January 14) ................................ 13

Figure 6. Maximum power level for each bus yard ........................................................................ 14

Figure 7. Lifetime NPV for diesel-hybrid only, immediate charging, and smart charging ...................... 15

Figure 8. Difference in lifetime NPV components from diesel-hybrid scenario .................................... 16

Figure 9. Average year-one electricity cost across all yards .............................................................. 17

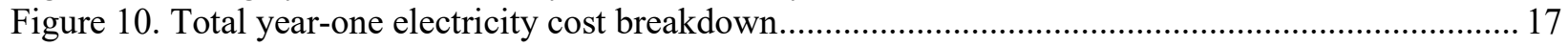

Figure 11. Comparison of the number of chargers required for each scenario ......................................... 18

Figure 12. Lifetime NPV cost breakdown for Cerone with additional PV ............................................ 19

Figure 13. Renewable generation and excess supply for Cerone with additional PV .............................. 19

Figure 14. Lifetime NPV cost breakdown for Cerone with storage and PV .........................................20

\section{List of Tables}

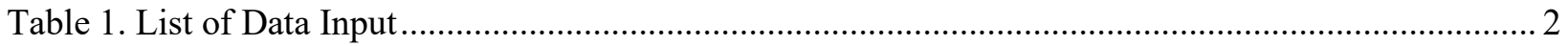

Table 2. Bus Energy Consumption for Different Bus Types ............................................................... 6

Table 3. Buses Eligible for Conversion to BEB Based on Charging Power Level and Intraday Charging

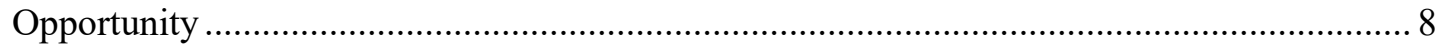

Table 4. Buses Eligible for Conversion to BEB Based on Charging Power Level and Intraday Charging

Opportunity by Bus Length..................................................................................... 9

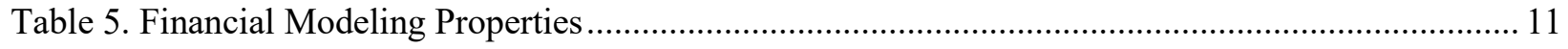

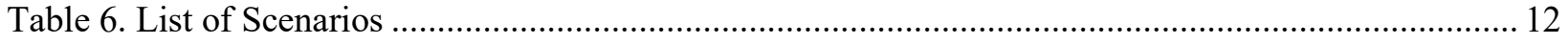




\section{Introduction}

As an opportunity to reduce operating costs for transit agencies, provide affordable mobility to customers, and reduce emissions, there is growing interest in electrifying transit buses. The California Air Resources Board (CARB) recently issued the Innovative Clean Transit (ICT) regulation (Title 13,2019$)$ that requires public transit agencies to gradually transition to 100 percent zero-emissions bus fleets by 2040. This means that both small and large transit fleets can only purchase zero-emission buses after 2029. As a result, transit agencies are now in the process of determining the best way to meet the new regulation.

This report explores the long-term electrification opportunities for the Santa Clara Valley Transportation Authority (VTA). VTA is an independent special district that provides bus, light rail, and paratransit services in California's Santa Clara County and surrounding counties. In 2019, VTA served an average of 114,600 riders per week resulting in an annual 26.9 million trips on buses and 8.3 million trips on rail. We examine the potential for transit bus electrification at VTA as well as the economic impacts of partial and complete electrification. We use an optimization model to determine the optimal electric bus selection and charging patterns to achieve the lowest cost solution at different levels of electrification. The cost minimization considers the bus capital cost, electricity cost, charger capital cost, bus maintenance cost, on-site photovoltaic panel cost, and stationary battery energy storage cost over the lifetime of the vehicles to determine the minimum system cost. 


\section{Input Data}

Developing a long-term electrification plan requires analysis of a significant amount of data as well as knowledge of both bus fleet operations and electricity systems. To characterize the potential to electrify a transit bus fleet we have developed a set of tools that combine the variety of data necessary to capture the main factors affecting electrification. A table of data sources is presented in Table 1 highlighting the necessary data sources for fleet electrification and optimization.

Table 1. List of Data Input

\begin{tabular}{|c|c|c|c|c|c|}
\hline$\#$ & Item & Source & Value(s) & Units & Description \\
\hline 1 & $\begin{array}{l}\text { Vehicle master } \\
\text { list }\end{array}$ & VTA & NA & NA & $\begin{array}{l}\text { Provides information about each bus } \\
\text { including bus id, length, and location }\end{array}$ \\
\hline 2 & $\begin{array}{l}\text { Vehicle incident } \\
\quad \log \end{array}$ & VTA & NA & NA & $\begin{array}{l}\text { Provides information about } \\
\text { scheduled and actual operation of } \\
\text { the buses each day (e.g., block id, } \\
\text { route id, vehicle id, timestamp). We } \\
\text { use } 22 \text { days of incident logs }\end{array}$ \\
\hline 3 & Route GPS traces & VTA & NA & NA & Shapefile data for bus routes \\
\hline 4 & $\begin{array}{l}\text { VTA bus } \\
\text { operation data }\end{array}$ & NREL & NA & NA & $\begin{array}{l}\text { NREL logged } 29 \text { buses for over } 3 \\
\text { weeks. Used to calculate bus } \\
\text { efficiency and diesel consumption for } \\
\text { hybrid buses }\end{array}$ \\
\hline 5 & $\begin{array}{l}\text { PG\&E electricity } \\
\text { consumption data }\end{array}$ & VTA/PG\&E & NA & NA & $\begin{array}{l}\text { 15-minute resolution electricity } \\
\text { consumption at VTA depots for one } \\
\text { year }\end{array}$ \\
\hline 6 & $\begin{array}{l}\text { Solar PV } \\
\text { production }\end{array}$ & VTA/SunPower & NA & NA & $\begin{array}{l}\text { 15-minute resolution PV production } \\
\text { for one year at each of the following } \\
\text { depots: } \\
\text { Cerone: } 969 \mathrm{~kW} \text {, Chaboya: } 548 \mathrm{~kW} \text {, } \\
\text { and North: } 637 \mathrm{~kW}\end{array}$ \\
\hline 7 & $\begin{array}{l}\text { Solar PV capital } \\
\text { cost }\end{array}$ & $\begin{array}{l}\text { NREL } 2019 \text { Annual } \\
\text { Technology Baseline, } \\
2019\end{array}$ & $\$ 1,111$ & $\$ / \mathrm{kW}$ & Current cost for utility-scale solar PV \\
\hline 8 & $\begin{array}{l}\text { Solar PV fixed } \\
\text { operation and } \\
\text { maintenance cost }\end{array}$ & $\begin{array}{l}\text { NREL } 2019 \text { Annual } \\
\text { Technology Baseline, } \\
2019\end{array}$ & $\$ 20$ & $\$ / k W$-year & Current cost for utility-scale solar PV \\
\hline 9 & $\begin{array}{l}\text { Li-ion battery } \\
\text { capital cost }\end{array}$ & $\begin{array}{l}\text { NREL } 2019 \text { Annual } \\
\text { Technology Baseline, } \\
2019\end{array}$ & 1323 & $\$ / k W$ & $\begin{array}{l}\text { Current low-cost estimate for a } 4 \\
\text { hour discharge duration system with } \\
\text { a 15-year lifetime }\end{array}$ \\
\hline 10 & $\begin{array}{l}\text { Li-ion battery } \\
\text { FOM cost }\end{array}$ & $\begin{array}{l}\text { NREL } 2019 \text { Annual } \\
\text { Technology Baseline, } \\
2019\end{array}$ & 33.08 & $\$ / k W-y r$ & $\begin{array}{l}\text { Current low-cost estimate for a } 4 \\
\text { hour discharge duration system with } \\
\text { a 15-year lifetime }\end{array}$ \\
\hline 11 & Charger capacity & & $\begin{array}{l}60 \text { or } \\
120\end{array}$ & $\mathrm{~kW}$ & Power levels for charging \\
\hline 12 & Charger cost & $\begin{array}{l}\text { VTA ( } 60 \mathrm{~kW} \text { actual } \\
\text { cost) } \\
\text { Estimate for } 120 \mathrm{~kW} \\
\text { charger }\end{array}$ & 40 or 90 & $\begin{array}{l}\text { Thousand } \\
\$ \$\end{array}$ & $\begin{array}{l}\text { Equipment cost for } 60 \mathrm{~kW} \text { and } 120 \\
\text { kW DCFC, respectively }\end{array}$ \\
\hline
\end{tabular}




\begin{tabular}{|c|c|c|c|c|c|}
\hline$\#$ & Item & Source & Value(s) & Units & Description \\
\hline 13 & Charger efficiency & & $95 \%$ & & $\begin{array}{l}\text { Efficiency of charger to deliver } \\
\text { electricity to bus }\end{array}$ \\
\hline 14 & $\begin{array}{l}\text { Charger } \\
\text { installation costs }\end{array}$ & VTA & 136,000 & $\begin{array}{l}\text { \$ per } \\
\text { charger }\end{array}$ & $\begin{array}{l}\text { Approximation based on actual costs } \\
\text { incurred to prepare the first several } \\
\text { chargers at Cerone }\end{array}$ \\
\hline 15 & BEB battery size & $\begin{array}{l}\text { VTA and National } \\
\text { Academies of } \\
\text { Sciences, Engineering, } \\
\text { and Medicine, } 2018\end{array}$ & 350,550 & $\begin{array}{l}\text { kWh, } \\
\text { usable }\end{array}$ & $\begin{array}{l}\text { Battery size for } 40 \text { ' Proterra buses } \\
\text { that VTA has on site and } 60 \text { ' BYD } \\
\text { buses from NAS report }\end{array}$ \\
\hline 16 & BEB capital cost & $\begin{array}{c}\text { VTA (actual for 40' } \\
\text { BEB) } \\
60 \text { ' bus cost is } \\
\text { interpolated based on } \\
\text { VTA hybrid bus costs }\end{array}$ & $\begin{array}{l}900 \text { and } \\
1,264\end{array}$ & $\begin{array}{l}\text { Thousand } \\
\$\end{array}$ & $40^{\prime}$ and $60^{\prime}$ bus costs, respectively \\
\hline 17 & $\begin{array}{l}\text { BEB maintenance } \\
\text { cost }\end{array}$ & $\begin{array}{c}\text { Eudy \& Jeffers, Zero- } \\
\text { Emission Bus } \\
\text { Evaluation Results: } \\
\text { King County Metro } \\
\text { Battery Electric Buses, } \\
2018\end{array}$ & 0.26 & $\$ /$ mile & Total maintenance cost \\
\hline 18 & $\begin{array}{l}\text { Diesel-hybrid bus } \\
\text { capital cost }\end{array}$ & VTA & $\begin{array}{l}700 \text { and } \\
983\end{array}$ & $\begin{array}{l}\text { Thousand } \\
\$\end{array}$ & $\begin{array}{l}40^{\prime} \text { and } 60^{\prime} \text { bus costs, respectively. } \\
\text { Excluding sales tax }\end{array}$ \\
\hline 19 & $\begin{array}{l}\text { Diesel-hybrid bus } \\
\text { maintenance cost }\end{array}$ & $\begin{array}{c}\text { Eudy \& Jeffers, Zero- } \\
\text { Emission Bus } \\
\text { Evaluation Results: } \\
\text { King County Metro } \\
\text { Battery Electric Buses, } \\
2018\end{array}$ & 0.32 & $\$ /$ mile & Total maintenance cost \\
\hline 20 & Diesel fuel cost & VTA & 2.44 & \$/gallon & Fuel cost for June 2018 \\
\hline 21 & Electric utility rate & PG\&E & NA & NA & $\begin{array}{l}\text { E20 - Industrial / general service }{ }^{3} \\
\text { It is assumed that the rate will remain } \\
\text { the same throughout the lifetime of } \\
\text { the system }\end{array}$ \\
\hline 22 & $\begin{array}{l}\text { Low Carbon Fuel } \\
\text { Standard (LCFS) } \\
\text { values }\end{array}$ & CARB & NA & NA & $\begin{array}{l}\text { LCFS credit price: } \$ 180 \\
\text { Heavy-duty bus energy economy } \\
\text { ratio: } 4.2 \\
2020 \text { grid carbon intensity: } 81.49 \mathrm{~g} \\
\mathrm{CO}_{2} \mathrm{e} / \mathrm{MJ} \\
2020 \text { diesel carbon intensity } \\
\text { standard: } 91.81 \mathrm{~g} \mathrm{CO}_{2} \mathrm{e} / \mathrm{MJ}\end{array}$ \\
\hline
\end{tabular}

\footnotetext{
${ }^{3}$ The rate structure used for this report can be found in the Utility Rate Database (https://openei.org/apps/USURDB/rate/view/5a3430585457a3e3595c48a2).
} 


\section{VTA Bus Eligibility for Electrification}

When examining potential for electrification at transit agencies, the first step is to understand the current route, ${ }^{4}$ block, and trip energy consumption requirements which can be achieved using vehicles currently in operation. After that, we explore potential changes that can increase the extent of electrification. These changes include quantitative assessment of charger power and enroute chargers, and qualitative assessments of battery size, purchasing extra buses, and route redesign.

\subsection{Modeling Methodology}

Using items 1-4 from Table 1, we can determine the energy consumption for all trips taken by diesel-hybrid buses and estimate an equivalent battery electric bus consumption. This also includes all time information, which is used to ensure that there is sufficient charging opportunity to meet the electricity consumption for each trip.

Since the diesel-hybrid buses at VTA have a similar range and occupancy capacity, many of the buses are interchangeable. As a result, the routing system can assign any bus that meets the requirements to the given route and block. That, in turn, means that buses could be serving different sets of blocks each day, so instead of recreating the exact trips for each bus we develop a method to take the set of all blocks that the VTA plans to run (including weekday and weekend blocks) and package them into a week of characteristic driving trips.

From millions of data points of timestamped route and block information we found that during the 22 day period that data was collected, 8707 blocks of work were performed by VTA buses. Of the 8707 blocks, only 497 are unique-many are repeated with slight variations day-to-day. We take the mode of all the repeated data to create 497 characteristic blocks from the data.

Next, we analyze the occurrence of each block by time of the day, which is important as several blocks are only run in the morning or evening to capture peak travel times. We then combine all available morning routes with appropriate evening routes to reduce the total number of vehicles required. This reduces the set from 497 blocks to 412 trips. Notice that by combining the blocks, they now represent daily trips. An example of trip information is shown in Figure 1. All data is shown in 15-minute increments.

\footnotetext{
${ }^{4}$ Transit system planners package a set of bus stops and scheduled stop times to meet customer needs into routes which are run one or more times each day. These routes are packaged into blocks which are assigned to a given bus. Each day a given bus can complete one or more blocks of work. The set of blocks completed are referred to in this report as trips.
} 


\begin{tabular}{|c|c|c|c|c|c|c|c|c|c|c|c|c|c|c|c|c|c|c|c|c|c|c|c|c|}
\hline Trip ID & 1 & 2 & 3 & 4 & 5 & 6 & 7 & 8 & 9 & 10 & 11 & 12 & 13 & 14 & 15 & 16 & 17 & 18 & 19 & 20 & 21 & 22 & \begin{tabular}{l|l}
23 & 24 \\
\end{tabular} & Trip ID \\
\hline 6808 & & & & & & & & & & & & & & & & & & & & & & & & 6808 \\
\hline 8145 & & & & & & & & & & & & & & & & & & & & & & & & 8145 \\
\hline 5441 & & & & & & & & & & & & & & & & & & & & & & & & 5441 \\
\hline $103 \mathrm{~A}$ & & & & & & & & & & & & & & & & & & & & & & & & $103 \mathrm{~A}$ \\
\hline 2518 & & & & & & & & & & & & & & & & & & & & & & & & 2518 \\
\hline 6046 & & & & & & & & & & & & & & & & & & & & & & & & 6046 \\
\hline $7102 \mathrm{~A}$ & & & & & & & & & & & & & & & & & & & & & & & & $7102 \mathrm{~A}$ \\
\hline 2314 & & & & & & & & & & & & & & & & & & & & & & & & 2314 \\
\hline $481 \mathrm{~A}$ & & & & & & & & & & & & & & & & & & & & & & & & $481 \mathrm{~A}$ \\
\hline $458 \mathrm{~A}$ & & & & & & & & & & & & & & & & & & & & & & & & $458 \mathrm{~A}$ \\
\hline 6823 & & & & & & & & & & & & & & & & & & & & & & & & 6823 \\
\hline 5343 & & & & & & & & & & & & & & & & & & & & & & & & 5343 \\
\hline 2341 & & & & & & & & & & & & & & & & & & & & & & & & 2341 \\
\hline 8203 & & & & & & & & & & & & & & & & & & & & & & & & 8203 \\
\hline 6823 & & & & & & & & & & & & & & & & & & & & & & & & 6823 \\
\hline 5872 & & & & & & & & & & & & & & & & & & & & & & & & 5872 \\
\hline 2241 & & & & & & & & & & & & & & & & & & & & & & & & 2241 \\
\hline 6809 & & & & & & & & & & & & & & & & & & & & & & & & 6809 \\
\hline 7173 & & & & & & & & & & & & & & & & & & & & & & & & 7173 \\
\hline
\end{tabular}

Figure 1. Example daily trip profiles for 20 random blocks (green $=$ available to charge, red $=$ en-route)

Similarly, we can also aggregate the trip data based on day of the week. Generally, we find that there are three types of trips resulting from the previous step: weekday trips, weekend trips, and trips that are run every day of the week. By combining weekday only and weekend only trips the total number of trips required each week is reduced from 412 to 404 .

Using the 404 weekly trips, we determine the equivalent energy consumption for electric buses and estimate how many trips are eligible for electrification using the bus parameters described in Table 1.

First, we examine the bus efficiency for different lengths and levels of efficiency in Table 2. While the current experience with Proterra 40' buses shows around $2 \mathrm{kWh} / \mathrm{mile}$, for the purpose of fleet-wide analysis, which includes a wider variety of routes, driving conditions, seasons, drivers, etc., we will use the average bus efficiency calculated using items $1-4$ in Table 1. 
Table 2. Bus Energy Consumption for Different Bus Types

\begin{tabular}{|c|c|c|c|c|}
\hline \multirow{2}{*}{$\begin{array}{c}\text { Properties by } \\
\text { bus type }\end{array}$} & \multicolumn{4}{|c|}{ Bus length } \\
\cline { 2 - 5 } & $\begin{array}{c}\text { Energy } \\
\text { consumption } \\
(\mathrm{kWh} / \mathrm{mile})\end{array}$ & $\begin{array}{c}\text { Standard } \\
\text { deviation } \\
(\mathrm{kWh} / \mathrm{mile})\end{array}$ & $\begin{array}{c}\text { Energy } \\
\text { consumption } \\
(\mathrm{kWh} / \mathrm{mile})\end{array}$ & $\begin{array}{c}\text { Standard } \\
\text { deviation } \\
(\mathrm{kWh} / \mathrm{mile})\end{array}$ \\
\hline Count of data items & 7758 & 7758 & 949 & 949 \\
\hline High efficiency bus & 1.92 & 0.15 & 2.53 & 0.44 \\
\hline Average efficiency bus & 2.33 & 0.25 & 2.94 & 0.41 \\
\hline Low efficiency bus & 2.75 & 0.06 & 3.36 & 0.48 \\
\hline
\end{tabular}

\subsection{Electrification Eligibility Results}

Current trips are designed to consider a variety of constraints including mobility needs, driver constraints, and bus constraints. As a result, they are sometimes designed with longer ranges than the selected BEB batteries can deliver. There are several methods that can increase BEB integration into transit fleets including (1) increasing charging power, (2) using buses with longer ranges, (3) en-route charging, (4) buying additional buses and swapping them to charge at a yard or transit center during the day, and (5) redesign routes/blocks to consider the BEB properties instead of conventional vehicles.

1. Increasing charger power allows for vehicles to more rapidly charge when they are available. This can enable electrification of routes where the vehicles are operating many hours a day and do not have much time to charge. Additionally, this can increase the flexibility of a fleet with smart charging and potentially reduce the number of chargers required to charge the fleet. Higher power chargers are more expensive to purchase and often marginally more expensive to install so the added benefit must outweigh the cost. Lastly, while this can enable electrification of typically long, low energy use routes, it does not enable routes that require longer range buses.

2. Using buses with longer range allows for longer routes to be assigned to the electric buses at the expense of additional cost and reduced efficiency for the bus, because of the added weight. In contrast to the previous item, larger batteries can enable electrification of high energy use routes but does not necessarily enable long, low energy use routes where charging time is a constraint. That is to say, if you have a large battery but don't have enough charger power or time to charge the battery, then buying a larger battery is not helpful.

3. En-route charging has been demonstrated in projects around the world. This can include fast charging at bus stops or transit centers or continuous charging via electrical contact (e.g., overhead catenary). Given VTA's system architecture we will focus on fast charging periodically along a route. This extends range or allows for smaller bus batteries which are typically less costly, however there are increased infrastructure costs and operational challenges. First, the chargers need to be high power, which often results in higher equipment and installation costs than a lower powered depot charger. Second, because of the high power, short duration electricity consumption profile the electricity 
cost to operate en-route chargers is typically higher than depot charging with more time available to shift and spread the charging load. Lastly, en-route charging can increase the usage and cycling of the battery contributing to reduced lifetimes (Muratori, Kontou, and Eichman 2019).

4. Another option is to purchase additional buses beyond the current fleet size which provides flexibility to charge buses during the day. For example, a daily trip of 200 miles is too long for a 40 ' BEB with a $440 \mathrm{kWh}(350 \mathrm{kWh}$ usable) battery pack to complete, but a second bus could be brought in to work together to complete the 200-mile trip and potentially other shorter trips as well. This method is for direct replacement of existing trips as opposed to the next item which is route redesign. Purchasing extra buses increases the capital costs for buses but not necessarily the charger costs and it likely allows for lower electricity cost, because the time that electricity is used can be managed to reduce the costs.

5. The final item discussed here is route redesign. Current routes and blocks were designed based on conventional bus properties. By redesigning the routes, considering BEB properties, it may be possible to achieve similar levels of service while enabling greater levels of BEBs. This process may require extensive work from VTA to perform the redesign, impact users, and while there are no direct costs, there may be indirect costs from additional buses or equipment to serve the same distances.

To understand the extent of electrification that is currently possible under the baseline assumptions and what is needed to increase this, we look at the impact of charging at points along the schedule. This could be done at a depot or during dwell times. Figure 2 shows the same trip itineraries in Figure 1 but also includes any dwell times that occurred for 15 minutes or more. Sometimes these appear at regular intervals for trips comprised of repeated blocks.

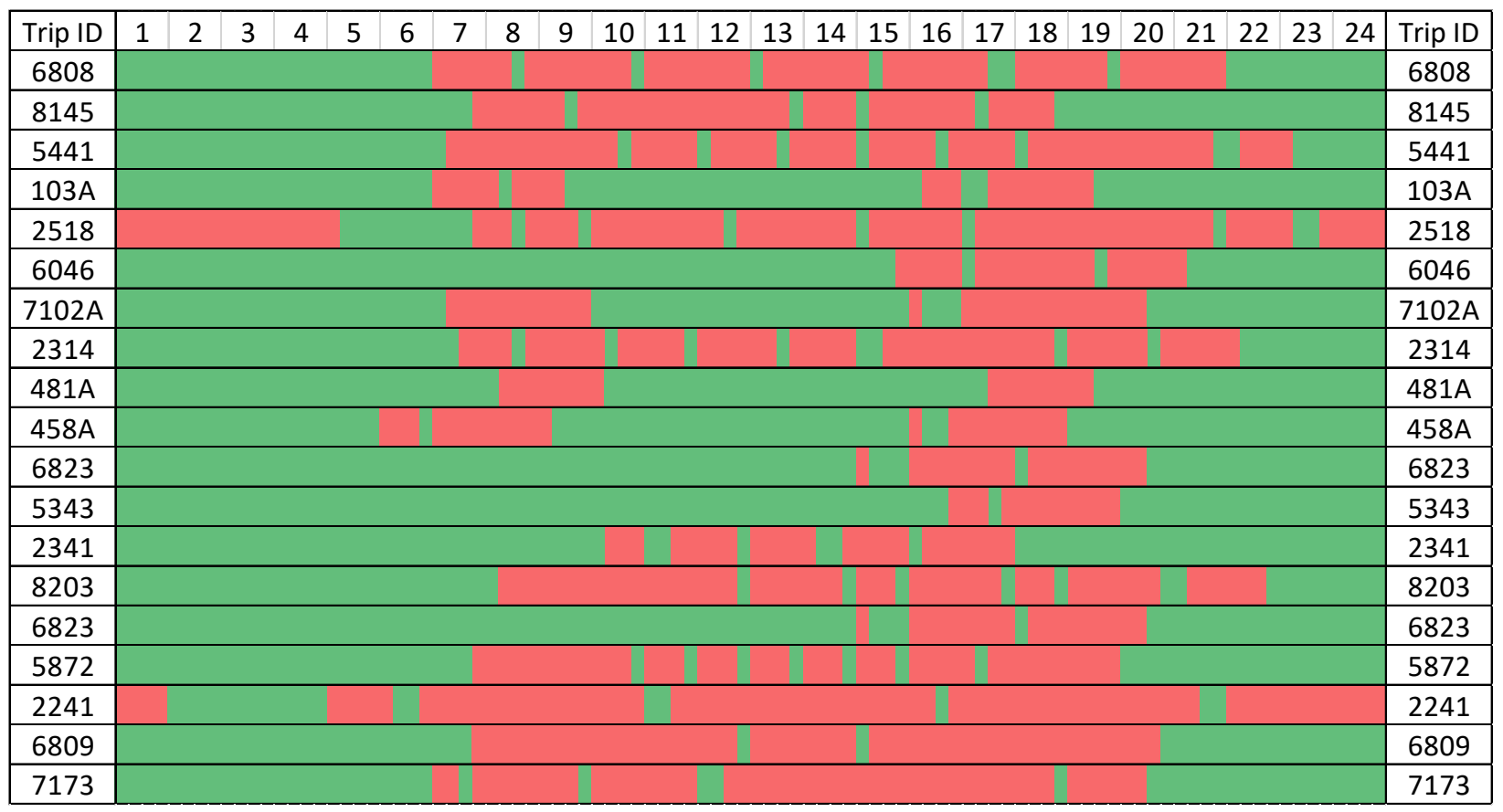

Figure 2. Example daily trip profiles for 20 random blocks including current dwell times of $15 \mathrm{~min}$ or more (green $=$ available to charge, red $=$ en-route) 
Combining results for only depot charging and charging during dwell times (Table 3 ) with only depot charging, VTA can electrify between $70 \%$ and $72 \%$ of the fleet, depending on the charging power used. By adding charging during already existing dwell times VTA can use BEBs without any additional changes for up to $98 \%$ of all trips. There are very few trips with dwell times of 1 hour and 30 minutes but there are a significant number of 15 -minute dwell events. Without considering the costs, the biggest enabler of bus electrification on existing routes is more charging opportunities during the day and not greater charging power.

Table 3. Buses Eligible for Conversion to BEB Based on Charging Power Level and Intraday Charging Opportunity

\begin{tabular}{|c|c|c|c|}
\hline \multirow{2}{*}{ Trip categories } & \multicolumn{3}{|c|}{ Charging level (kW) } \\
\hline & 60 & 120 & 350 \\
\hline Total trips & 404 & 404 & 404 \\
\hline $\begin{array}{l}\text { Eligible for BEBs with charging at the } \\
\text { depot }\end{array}$ & $\begin{array}{c}284 \\
(70 \%)\end{array}$ & $\begin{array}{c}291 \\
(72 \%)\end{array}$ & $\begin{array}{c}291 \\
(72 \%)\end{array}$ \\
\hline $\begin{array}{l}\text { Eligible for BEBs with charging during } \\
\text { dwell times of 1-hour or more }\end{array}$ & $\begin{array}{c}284 \\
(70 \%)\end{array}$ & $\begin{array}{c}291 \\
(72 \%)\end{array}$ & $\begin{array}{c}291 \\
(72 \%)\end{array}$ \\
\hline $\begin{array}{l}\text { Eligible for BEBs with charging during } \\
\text { dwell times of } 30 \text {-minutes or more }\end{array}$ & $\begin{array}{c}293 \\
(73 \%)\end{array}$ & $\begin{array}{l}305 \\
(75 \%)\end{array}$ & $\begin{array}{l}307 \\
(76 \%)\end{array}$ \\
\hline $\begin{array}{l}\text { Eligible for BEBs with charging during } \\
\text { dwell times of } 15 \text {-minutes or more }\end{array}$ & $\begin{array}{c}344 \\
(85 \%)\end{array}$ & $\begin{array}{c}381 \\
(94 \%)\end{array}$ & $\begin{array}{c}397 \\
(98 \%)\end{array}$ \\
\hline
\end{tabular}

More detail about the trips that can be electrified by length of bus is shown in Table 4. Notice that trips served by buses that are 40 -foot or less are easier to electrify than the routes served by 60 -foot buses. In this case, high-power charging becomes much more important to enable electrification, to shorten the charging time and make use of the available hours.

The buses are out on routes most of the day, with the maximum value being 21.5 hours or $90 \%$ of the day. For these high use routes there is not much time for charging, but with sufficiently high-power charging or additional intraday charging opportunities, the routes are still able to be converted. For this analysis we consider $350 \mathrm{~kW}$ chargers, which is acceptable for charging electric buses. As an example, Foothill Transit has a $500 \mathrm{~kW}$ bus fast charging system (Eudy et al. 2016). 
Table 4. Buses Eligible for Conversion to BEB Based on Charging Power Level and Intraday Charging Opportunity by Bus Length

\begin{tabular}{|l|l|c|c|c|c|c|c|}
\hline \multirow{2}{*}{$\begin{array}{l}\text { Trip } \\
\text { categories }\end{array}$} & \multicolumn{2}{|c|}{60} & \multicolumn{2}{c|}{120} & \multicolumn{2}{c|}{350} \\
\cline { 2 - 8 } & Bus length (feet) & $\leq 40$ & 60 & $\leq 40$ & 60 & $\leq 40$ & 60 \\
\cline { 2 - 8 } & Battery size (kWh usable) & 350 & 550 & 350 & 550 & 350 & 550 \\
\hline Total trips & 359 & 45 & 359 & 45 & 359 & 45 \\
\hline $\begin{array}{l}\text { Eligible for BEBs with charging at the } \\
\text { depot }\end{array}$ & $\begin{array}{c}264 \\
(74 \%)\end{array}$ & $\begin{array}{c}20 \\
(44 \%)\end{array}$ & $\begin{array}{c}264 \\
(74 \%)\end{array}$ & $\begin{array}{c}27 \\
(60 \%)\end{array}$ & $\begin{array}{c}264 \\
(74 \%)\end{array}$ & $\begin{array}{c}27 \\
(60 \%)\end{array}$ \\
\hline $\begin{array}{l}\text { Eligible for BEBs with charging during } \\
\text { dwell times of 1-hour or more }\end{array}$ & $\begin{array}{c}264 \\
(74 \%)\end{array}$ & $\begin{array}{c}20 \\
(44 \%)\end{array}$ & $\begin{array}{c}264 \\
(74 \%)\end{array}$ & $\begin{array}{c}27 \\
(60 \%)\end{array}$ & $\begin{array}{c}264 \\
(74 \%)\end{array}$ & $\begin{array}{c}27 \\
(60 \%)\end{array}$ \\
\hline $\begin{array}{l}\text { Eligible for BEBs with charging during } \\
\text { dwell times of 30-minutes or more }\end{array}$ & $\begin{array}{c}273 \\
(76 \%)\end{array}$ & $\begin{array}{c}20 \\
(44 \%)\end{array}$ & $\begin{array}{c}278 \\
(77 \%)\end{array}$ & $\begin{array}{c}27 \\
(60 \%)\end{array}$ & $\begin{array}{c}280 \\
(78 \%)\end{array}$ & $\begin{array}{c}27 \\
(60 \%)\end{array}$ \\
\hline $\begin{array}{l}\text { Eligible for BEBs with charging during } \\
\text { dwell times of 15-minutes or more }\end{array}$ & $\begin{array}{c}321 \\
(89 \%)\end{array}$ & $\begin{array}{c}23 \\
(51 \%)\end{array}$ & $\begin{array}{c}346 \\
(96 \%)\end{array}$ & $\begin{array}{c}35 \\
(78 \%)\end{array}$ & $\begin{array}{c}356 \\
(99 \%)\end{array}$ & $\begin{array}{c}41 \\
(91 \%)\end{array}$ \\
\hline
\end{tabular}

While this establishes the potential, each of the assumptions made represents potentially significant costs, or operation complications for a transit agency. Finding a way to cost effectively charge buses to enable a full fleet conversion is the challenge. Given these results, it is imaginable that some combination of route redesign, bus design choices, and intraday charging can result in complete electrification at the lowest cost. This idea will be discussed in the following sections in more detail. 


\section{Optimal Bus Electrification}

There are many moving pieces to consider when determining the lowest cost option for fleet electrifications. To appropriately model the trade-offs, we utilized the open-sourced Revenue Operation and Device Optimization Model (RODeO) (Denholm, Eichman, and Margolis 2017; Eichman et al. 2020; Eichman, Townsend, and Melaina 2016; Eichman and Flores-Espino 2016), which can be found at https://github.com/NREL/RODeO/. RODeO can simultaneously determine the optimal charging patterns for hundreds of buses. The optimization also considers existing electricity consumption at the facility, on-site renewables, credits and incentives, financing structure, taxes, debt, etc.

\subsection{RODeO Model}

RODeO takes a variety of inputs (shown in Figure 3) and solves the mixed integer linear programming problem to maximize the net revenue for a given device(s). For utility service, we assume that all three bus yards take service under the retail E20 rate from PG\&E. The buses do not participate in wholesale energy or ancillary service markets. Early analysis on this project found relatively little revenue potential with ancillary services, which is not to say it is not worth pursuing, but rather, we have prioritized exploring other items in this report. The model is run with hourly resolution to reduce computation time of simultaneously optimizing hundreds of buses.

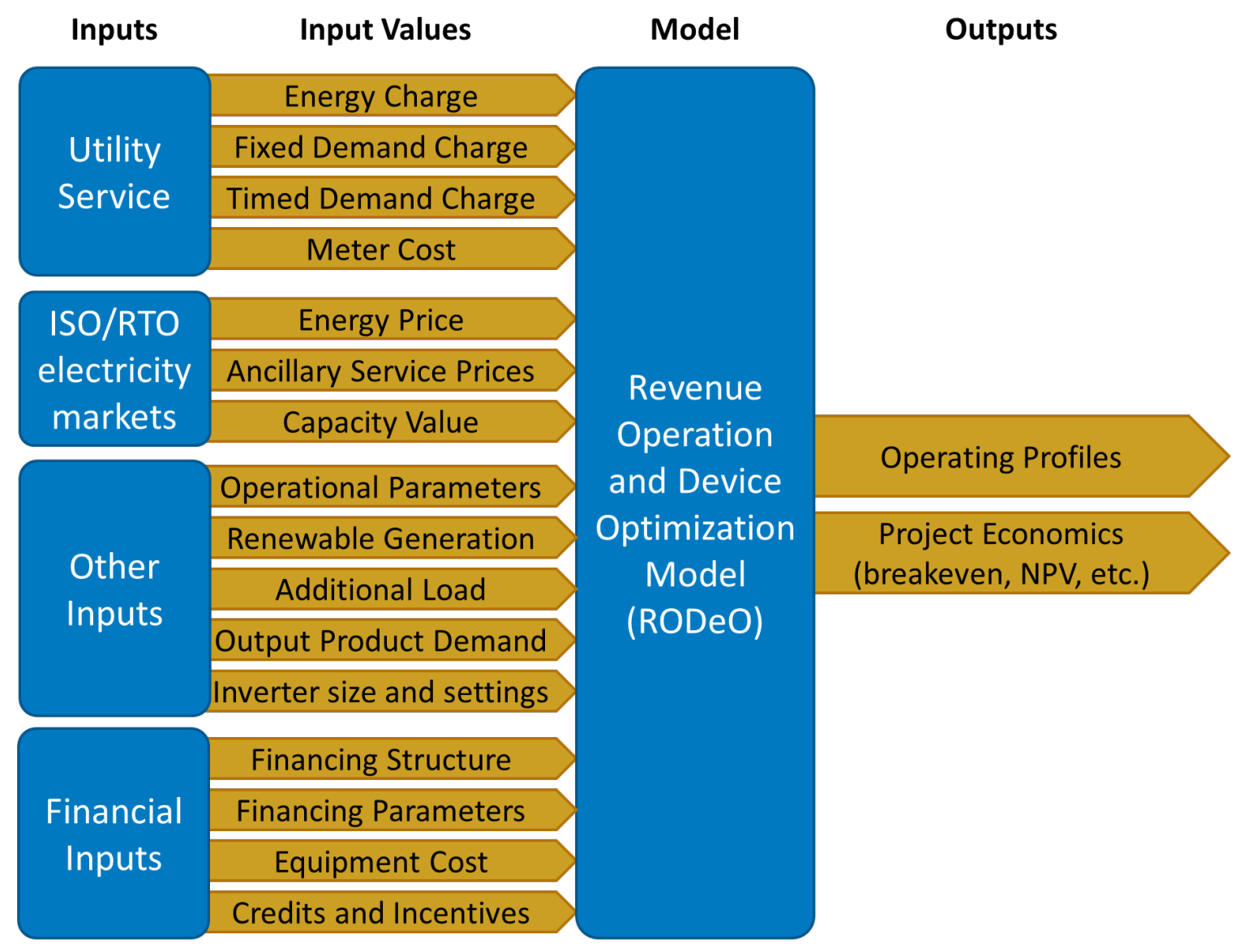

Figure 3. Revenue Operation and Device Optimization modeling framework 
Financial assumptions are listed in Table 5. These properties are used to model all scenarios. The economic lifetime of the system is assumed to be 15 years. The buses must operate at least 12 years but, as it is often the case with the current buses, the buses can operate for more than the minimum 12 years. VTA is assumed to have no income tax. The weighted average cost of capital (WACC) is assumed to be $7.0 \%$ with a debt to equity split of $58.1 \% / 41.9 \%$. Without any tax burden, tax credits and incentives do not have an effect. That includes the MACRS depreciation, which would normally help reduce taxes on remaining asset value.

Table 5. Financial Modeling Properties

\begin{tabular}{|l|c|}
\hline \multicolumn{1}{|c|}{ Property } & Value or description \\
\hline WACC & $7.0 \%$ \\
\hline Economic lifetime & 15 years \\
\hline Equity fraction & $41.9 \%$ \\
\hline Debt fraction & $58.1 \%$ \\
\hline Debt interest rate & $4.81 \%$ \\
\hline $\begin{array}{l}\text { Combined federal and state } \\
\text { income tax rate }\end{array}$ & $0 \%$ \\
\hline Depreciation & $\begin{array}{l}\text { MACRS 5-year depreciation schedule with an } \\
\text { additional 50\% bonus depreciation }\end{array}$ \\
\hline
\end{tabular}

\subsection{Scenarios Considered}

The following scenarios (Table 6) were implemented to consider the locational impacts, charger sizing, intraday charging potential, and effects of increased PV. These scenarios provide an understand of the total cost to convert the entire fleet to battery electric vehicles and the tradeoffs.

The scenarios are grouped together by like properties. Scenario 1, with diesel-hybrid buses, represents a business-as-usual case (BAU) and a comparison to understand the cost implications for converting the fleet to battery electric buses. Scenario group 2 includes immediate charging for different charging power levels and different intraday charging opportunities. Due to the charging needs for some trips, scenarios without intraday charging will not result in a full fleet conversion, while those with intraday charging are able to accommodate full fleet electrification. Scenario group 3 introduces smart charging for the same items in group 2. Smart charging reduces the system cost as much as possible by changing when the vehicles charge. Scenario group 4 introduces increased levels of PV to understand the benefits of additional onsite renewables. Scenario group 5 explores the installation of battery energy storage, and scenario 6 includes a combination of both PV and batteries. 
Table 6. List of Scenarios

\begin{tabular}{|c|c|c|c|c|c|c|c|}
\hline$\#$ & Short name & Yard(s) & Bus type & $\begin{array}{l}\text { Intraday } \\
\text { charging }\end{array}$ & $\begin{array}{l}\text { Charging } \\
\text { power } \\
\text { (kW) }\end{array}$ & $\begin{array}{l}\text { Charging } \\
\text { strategy }\end{array}$ & $\begin{array}{l}\text { Other } \\
\text { technology }\end{array}$ \\
\hline 1 & BAU & $\begin{array}{c}\text { Cerone, } \\
\text { Chaboya, North }\end{array}$ & Diesel-hybrid & N/A & $\mathrm{N} / \mathrm{A}$ & N/A & N/A \\
\hline 2.1 & $\begin{array}{l}\text { Immediate low } \\
\text { power }\end{array}$ & $\begin{array}{c}\text { Cerone, } \\
\text { Chaboya, North }\end{array}$ & $\begin{array}{l}\text { Battery } \\
\text { electric bus }\end{array}$ & No & 60 & Immediate & N/A \\
\hline 2.2 & $\begin{array}{l}\text { Immediate high } \\
\text { power }\end{array}$ & $\begin{array}{c}\text { Cerone, } \\
\text { Chaboya, North }\end{array}$ & $\begin{array}{l}\text { Battery } \\
\text { electric bus }\end{array}$ & No & 120 & Immediate & N/A \\
\hline 2.3 & $\begin{array}{l}\text { Immediate low } \\
\text { power plus intraday }\end{array}$ & $\begin{array}{c}\text { Cerone, } \\
\text { Chaboya, North }\end{array}$ & $\begin{array}{l}\text { Battery } \\
\text { electric bus }\end{array}$ & Yes & 60 & Immediate & N/A \\
\hline 2.4 & $\begin{array}{l}\text { Immediate high } \\
\text { power plus intraday }\end{array}$ & $\begin{array}{c}\text { Cerone, } \\
\text { Chaboya, North }\end{array}$ & $\begin{array}{l}\text { Battery } \\
\text { electric bus }\end{array}$ & Yes & 120 & Immediate & $\mathrm{N} / \mathrm{A}$ \\
\hline 3.1 & Smart low power & $\begin{array}{c}\text { Cerone, } \\
\text { Chaboya, North }\end{array}$ & $\begin{array}{l}\text { Battery } \\
\text { electric bus }\end{array}$ & No & 60 & Smart & $\mathrm{N} / \mathrm{A}$ \\
\hline 3.2 & Smart high power & $\begin{array}{l}\text { Cerone, } \\
\text { Chaboya, North }\end{array}$ & $\begin{array}{l}\text { Battery } \\
\text { electric bus }\end{array}$ & No & 120 & Smart & N/A \\
\hline 3.3 & $\begin{array}{l}\text { Smart low power } \\
\text { plus intraday }\end{array}$ & $\begin{array}{c}\text { Cerone, } \\
\text { Chaboya, North }\end{array}$ & $\begin{array}{l}\text { Battery } \\
\text { electric bus }\end{array}$ & Yes & 60 & Smart & N/A \\
\hline 3.4 & $\begin{array}{l}\text { Smart high power } \\
\text { plus intraday }\end{array}$ & $\begin{array}{c}\text { Cerone, } \\
\text { Chaboya, North }\end{array}$ & $\begin{array}{l}\text { Battery } \\
\text { electric bus }\end{array}$ & Yes & 120 & Smart & N/A \\
\hline 4.1 & 1x PV & Cerone & $\begin{array}{l}\text { Battery } \\
\text { electric bus }\end{array}$ & Yes & 60 & Smart & $P V x 1$ \\
\hline 4.2 & $2 x P V$ & Cerone & $\begin{array}{l}\text { Battery } \\
\text { electric bus }\end{array}$ & Yes & 60 & Smart & $P V x 2$ \\
\hline 4.3 & $3 x P V$ & Cerone & $\begin{array}{l}\text { Battery } \\
\text { electric bus }\end{array}$ & Yes & 60 & Smart & $P V \times 3$ \\
\hline 4.4 & $4 x P V$ & Cerone & $\begin{array}{l}\text { Battery } \\
\text { electric bus }\end{array}$ & Yes & 60 & Smart & PV $x 4$ \\
\hline 5.1 & $0.5 \mathrm{MW}$ battery & Cerone & $\begin{array}{l}\text { Battery } \\
\text { electric bus }\end{array}$ & Yes & 60 & Smart & $\begin{array}{l}\text { 0.5-MW, 4- } \\
\text { MWh battery }\end{array}$ \\
\hline 5.2 & $1 \mathrm{MW}$ battery & Cerone & $\begin{array}{l}\text { Battery } \\
\text { electric bus }\end{array}$ & Yes & 60 & Smart & $\begin{array}{c}\text { 1-MW, 4-MWh } \\
\text { battery }\end{array}$ \\
\hline 5.3 & $2 \mathrm{MW}$ battery & Cerone & $\begin{array}{l}\text { Battery } \\
\text { electric bus }\end{array}$ & Yes & 60 & Smart & $\begin{array}{c}\text { 2-MW, 4-MWh } \\
\text { battery }\end{array}$ \\
\hline 5.4 & $3 \mathrm{MW}$ battery & Cerone & $\begin{array}{l}\text { Battery } \\
\text { electric bus }\end{array}$ & Yes & 60 & Smart & $\begin{array}{c}\text { 3-MW, 4-MWh } \\
\text { battery }\end{array}$ \\
\hline 5.5 & $4 \mathrm{MW}$ battery & Cerone & $\begin{array}{l}\text { Battery } \\
\text { electric bus }\end{array}$ & Yes & 60 & Smart & $\begin{array}{c}\text { 4-MW, 4-MWh } \\
\text { battery }\end{array}$ \\
\hline 6 & $\begin{array}{c}4 \mathrm{MW} \text { battery }+4 \mathrm{x} \\
\text { PV }\end{array}$ & Cerone & $\begin{array}{l}\text { Battery } \\
\text { electric bus }\end{array}$ & Yes & 60 & Smart & $\begin{array}{c}\text { 4-MW, 4-MWh } \\
\text { battery and } 4 \mathrm{x} \\
\mathrm{PV}\end{array}$ \\
\hline
\end{tabular}




\subsection{Bus Charging Patterns}

Running an optimization of the scenarios in Table 6 results in both economic information and operation information. This section explores the resulting operation information to provide some expectation of the expected operation.

The hourly bus electricity consumption for the entire fleet (including all three bus yards) is shown in Figure 4. Immediate charging experiences a higher maximum value as well as more prolonged periods of unused equipment, while the smart charging smooths out operation. This will translate to electricity cost savings, particularly with the demand charge and will be discussed in greater detail in the next section.

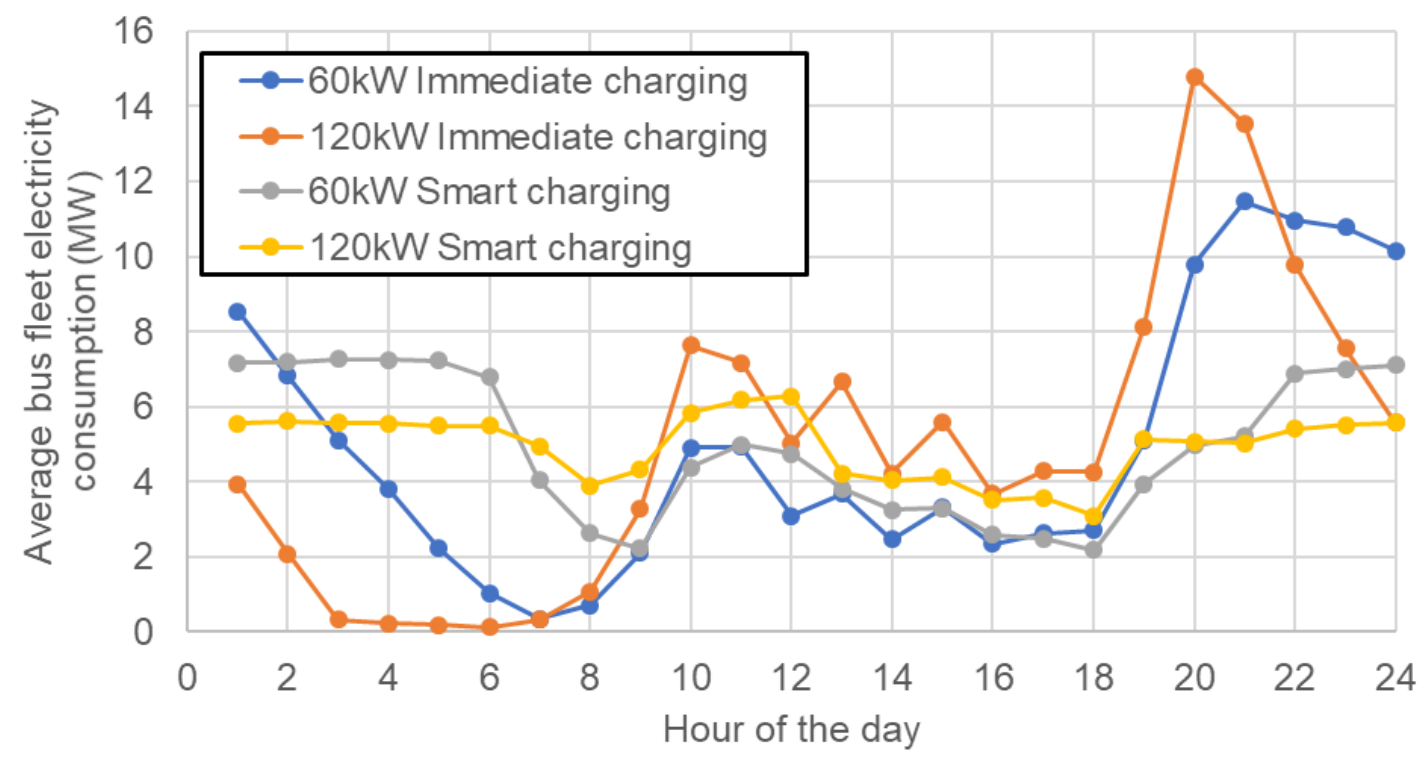

Figure 4. Average daily electricity consumption profile for full fleet electrification

Figure 5 shows that the trips include heavier usage during the weekday than the weekend, which is to be expected with the Monday through Friday work week.

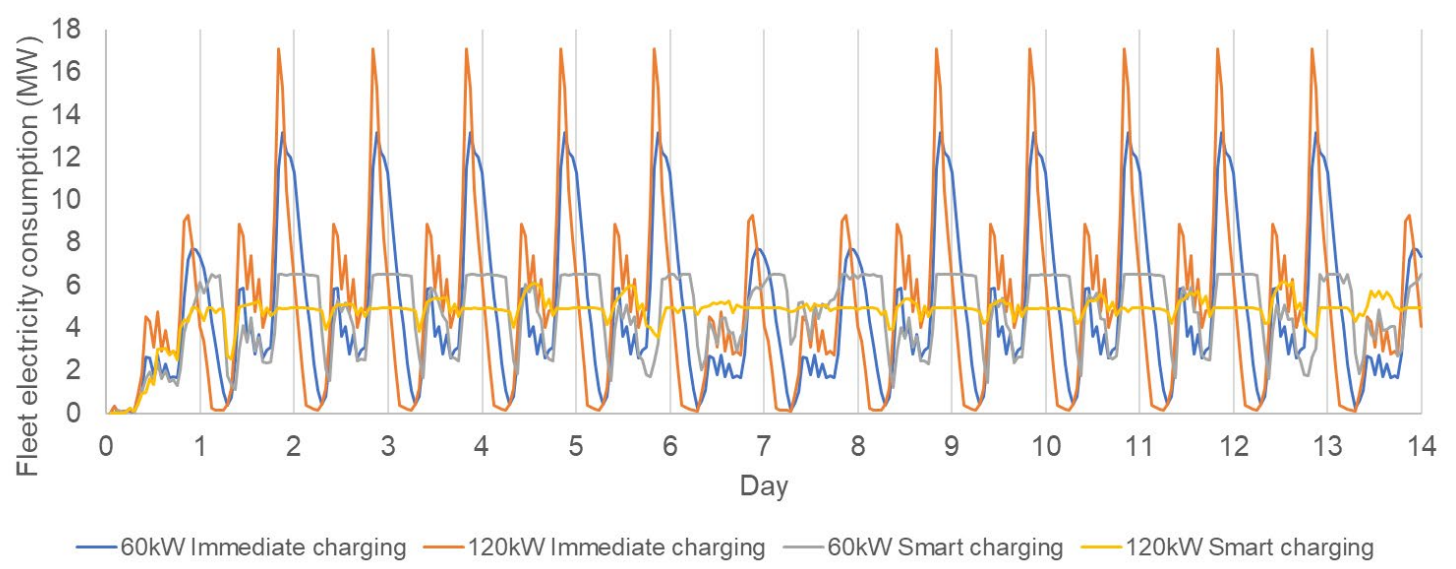

Figure 5. Example week of fleet electricity consumption (January 1-January 14) 
It is also important to understand the extent of electrical upgrades that might be necessary to support bus electrification. Figure 6 shows the maximum power levels for immediate and smart charging. Not surprisingly, the immediate charging has much higher site power requirements with a maximum of 6.1 MW for Cerone, 6.9 MW for Chaboya, and 5.2 MW for the North yard (including additional non-bus-related facility load). Smart charging can reduce the site power requirements by between $31 \%$ and $65 \%$. When discussing the level of electrical upgrades with the utility is it important to use this kind of study to characterize the maximum amount of demand. Without this knowledge the utilities could default to a worst-case scenario where all vehicles are charged at once ${ }^{5}$ and make the transit agency upgrade more than is necessary. Based on the driving schedules, the worst-case scenario is not likely to ever occur and from Figure 6, even with immediate charging, the maximum power is much lower. In summary, communication with the utility is important to help minimize the required upgrade and resulting costs.

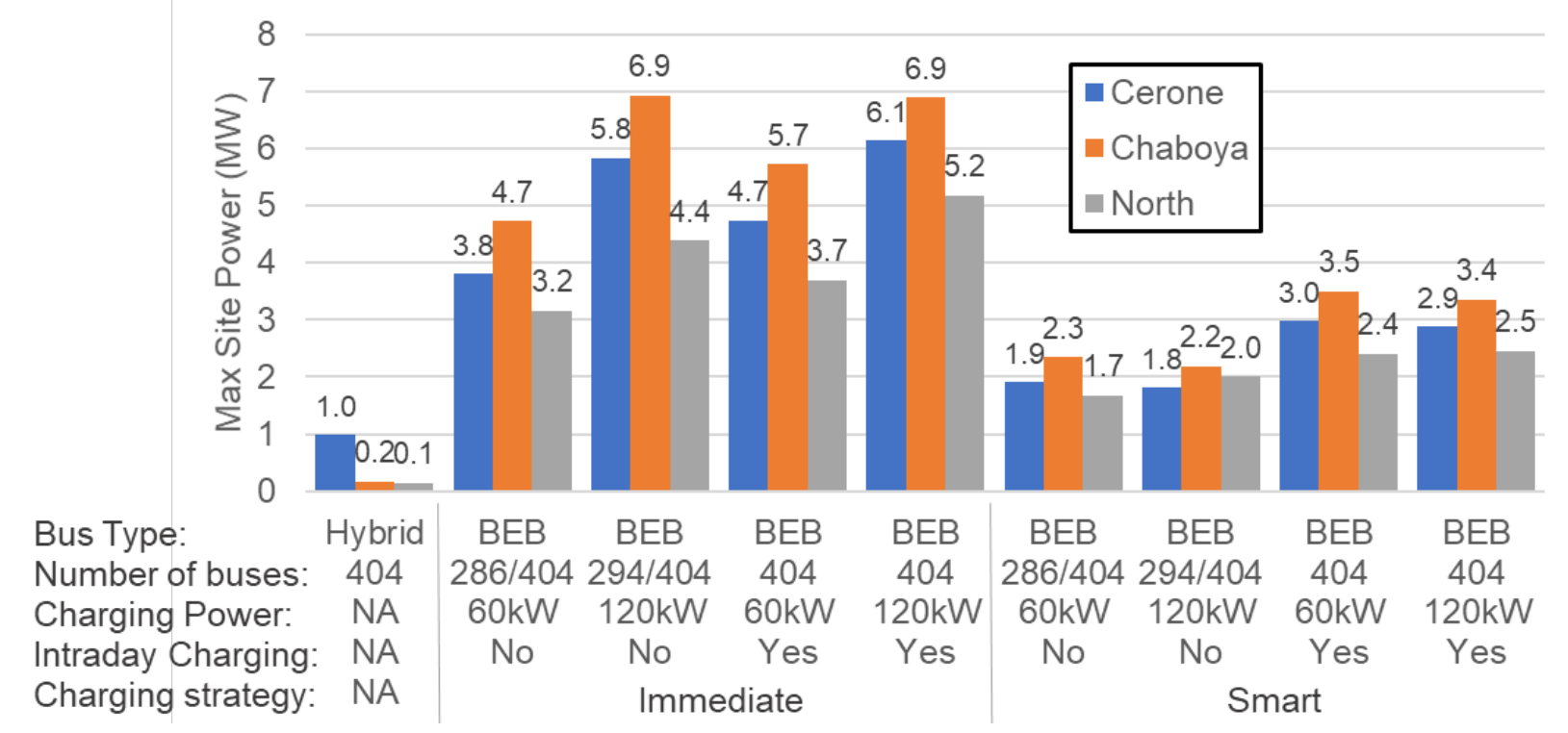

Figure 6. Maximum power level for each bus yard

\subsection{Lifetime Cost Comparison}

Several studies have found that BEBs can reduce the operating cost (i.e., \$/mile) but it is more challenging to determine the lifetime cost of operating a diesel-hybrid bus compared to a BEB. Using the method described above, we can capture the lifetime costs for different methods of providing transportation services. Figure 7 shows the lifetime net present value (NPV) results for scenarios 1-3 from Table 6. LCFS revenue represents revenue by offsetting diesel emissions of heavy-duty buses. Electricity cost includes all the cost components from the utility rate (i.e., energy charge, demand charge, meter charge). FOM cost includes the fixed operation and maintenance cost for all the equipment. Diesel fuel cost includes the cost for diesel fuel. Capital cost consists of the upfront capital cost as well as debt payments for all equipment and installation costs.

\footnotetext{
${ }^{5}$ For all BEBs that equates to 7.2 MW at Cerone, $10 \mathrm{MW}$ at Chaboya, and $7 \mathrm{MW}$ at the North Yard.
} 
Each stacked bar represents the lifetime NPV costs for all buses over the next 15 years. It is assumed that the electricity rate structure, FOM costs, LCFS credit value, and diesel cost do not change over that time.

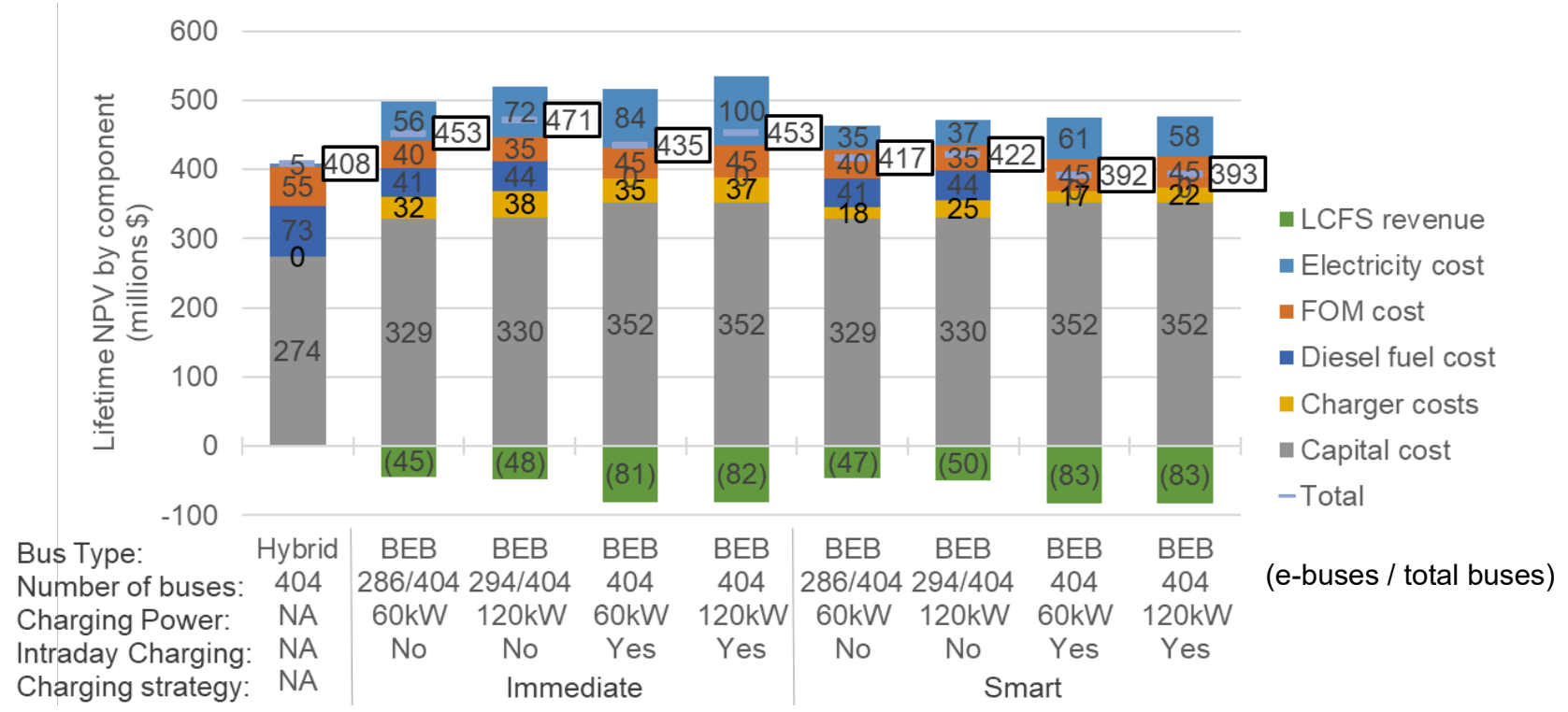

Figure 7. Lifetime NPV for diesel-hybrid only, immediate charging, and smart charging

Scenarios are separated into three sections. The first stacked bar on the left is the base case (business-as-usual) where all buses are diesel hybrids, the next four bars include partial and full fleet electrification utilizing only immediate charging, and the last four bars include partial and full fleet electrification utilizing smart charging. The results show that smart charging system costs are within $\pm 4 \%$ of the lifetime NPV cost of the diesel-hybrid only (business-as-usual) scenario. Partial electrification scenarios (i.e., no intraday charging) are $2 \%-3 \%$ greater than the diesel-hybrid scenario, while the full electrification scenario (i.e., with intraday charging) is $4 \%$ lower. Scenarios with intraday charging assume that there are additional times available for the buses to charge, but no equipment cost is assigned to enable that charging (i.e., no en-route charging, no additional transit center chargers). Given the options to increase electrification levels discussed in Section 3.2, the range of costs could be zero if route redesign is sufficient or millions of dollars if additional en-route charging, larger batteries, or extra buses are required. This report is a first step in the direction of determining those costs. By better understanding how the system is operating and the needs to encourage electrification we can create a clearer picture of what a fully electrified system can look like.

By comparing the differences in cost elements (shown in Figure 8), it becomes clear that compared to the diesel-hybrid scenario, BEB scenarios have higher capital costs, charger costs and electricity costs, but reduce the diesel fuel costs, fixed operation and maintenance costs and also increase revenue from LCFS credits. The LCFS credit plays an important role in offsetting the additional capital cost. 


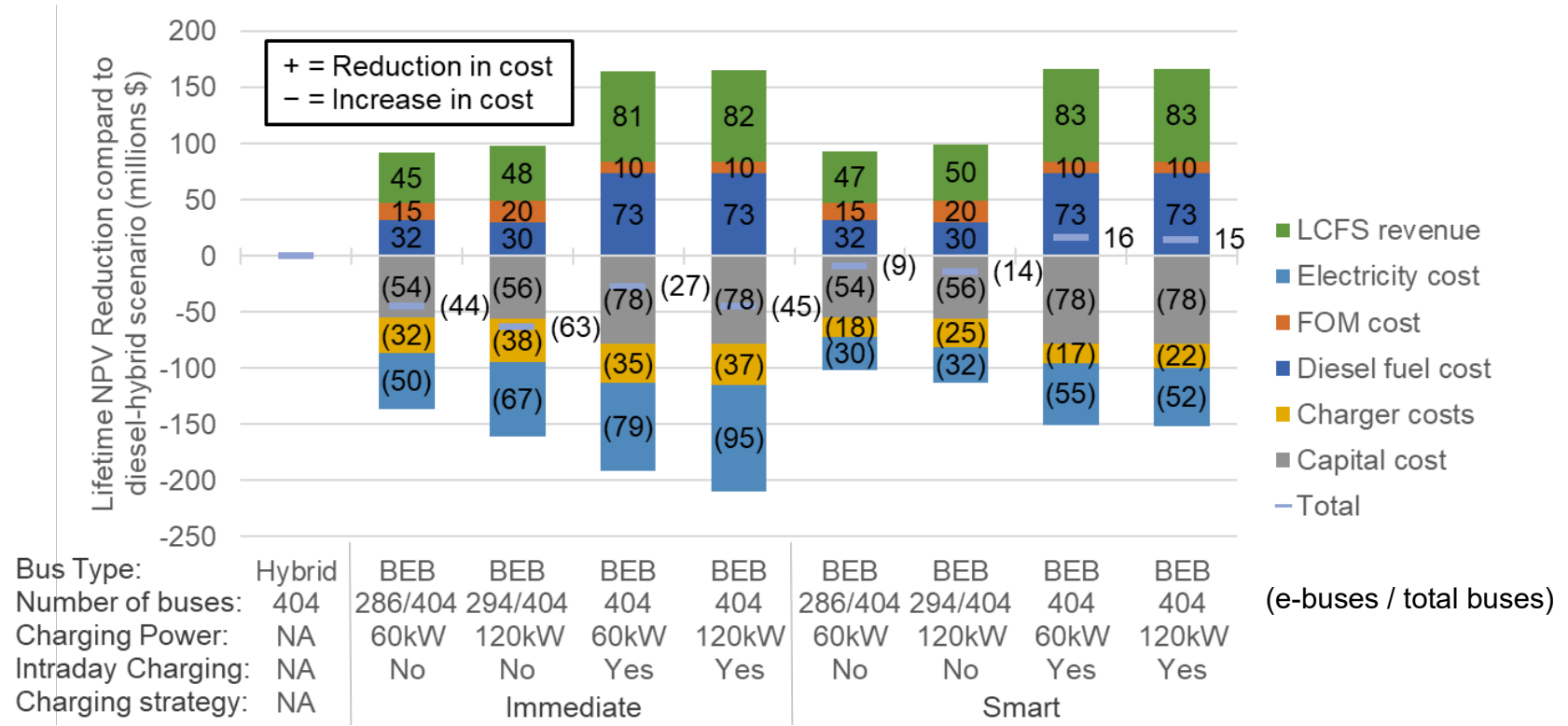

Figure 8. Difference in lifetime NPV components from diesel-hybrid scenario

Every scenario with immediate charging has a higher cost than the smart charging equivalent. Additional lifetime NPV costs for immediate versus smart charging range from \$36 to \$59 million, mostly from the cost of electricity followed by charger cost. With that amount of potential savings over the project lifetime, it is strongly recommended to pursue smart charging even for partial electrification plans.

The $120 \mathrm{~kW}$ chargers consistently result in an increase in the total cost, despite adding flexibility by allowing for vehicles to charge more rapidly. This means that, given our cost assumptions, the added cost for $120 \mathrm{~kW}$ chargers is not offset by enough of a reduction in electricity cost to make their purchase economically feasible.

\subsection{Electricity Cost Impacts}

By combining all the electricity cost components and dividing by the total electricity use in $\mathrm{kWh}$ we can determine an average cost of purchasing electricity for each scenario (Figure 9). All scenarios take electricity service under the same utility rate so difference in average electricity cost is driven by the time that the electricity is used. Results show that immediate charging of buses will result in an increase in the average electricity cost compared to the current all dieselhybrid bus scenario; however, smart charging will result in a reduction in the average electricity cost. While the cost results in Figure 7 do not show sufficient value for $120 \mathrm{~kW}$ chargers to be installed over $60 \mathrm{~kW}$, higher power charging does enable greater flexibility and as a result can slightly reduce electricity cost. 


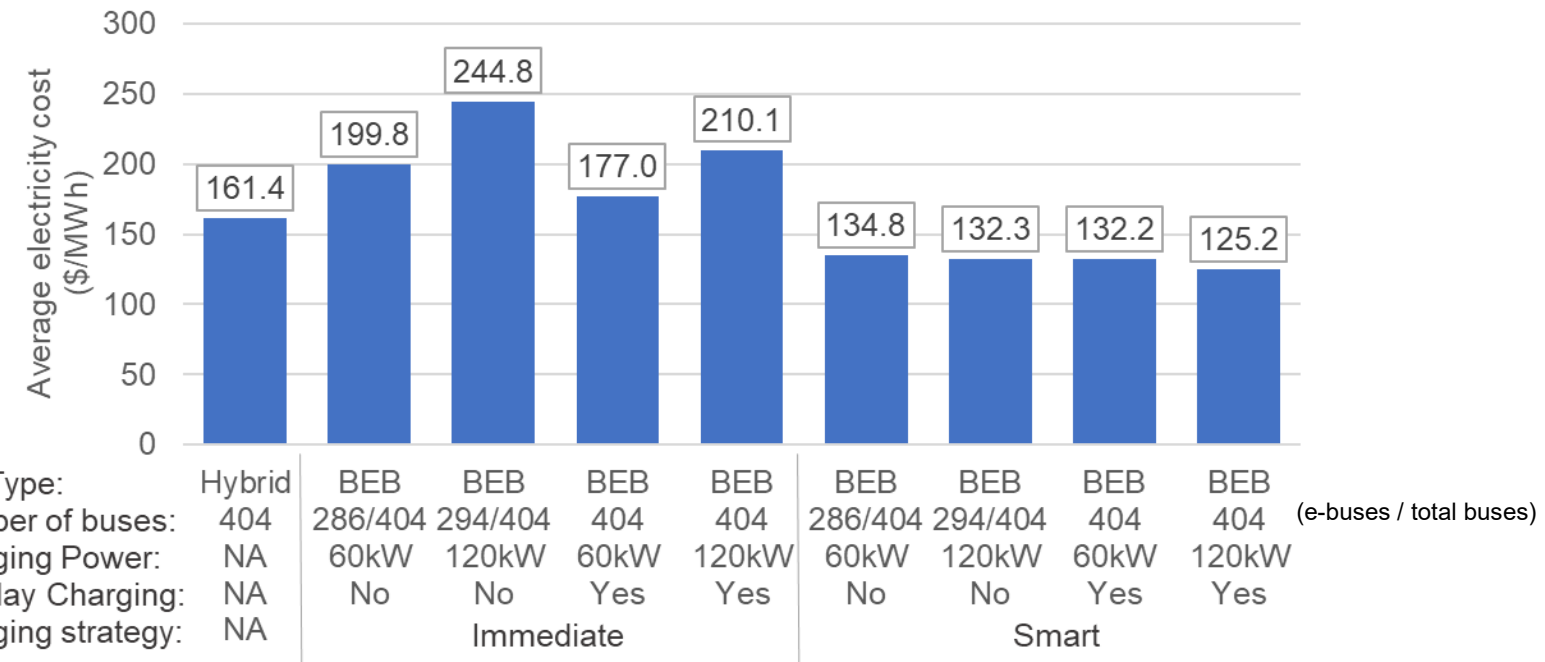

Figure 9. Average year-one electricity cost across all yards

We can see more clearly why the electricity cost is lower for smart charging than immediate charging in Figure 10. The meter charge is the same and the energy charge values are roughly the same, but the demand charge values are significantly lower on account of the ability to stagger the time of consumption. The time-of-use pattern for Pacific Gas and Electric's E-20 commercial utility rate can be seen in the Utility Rate Database (https://openei.org/apps/USURDB/rate/view/5a3430585457a3e3595c48a2).

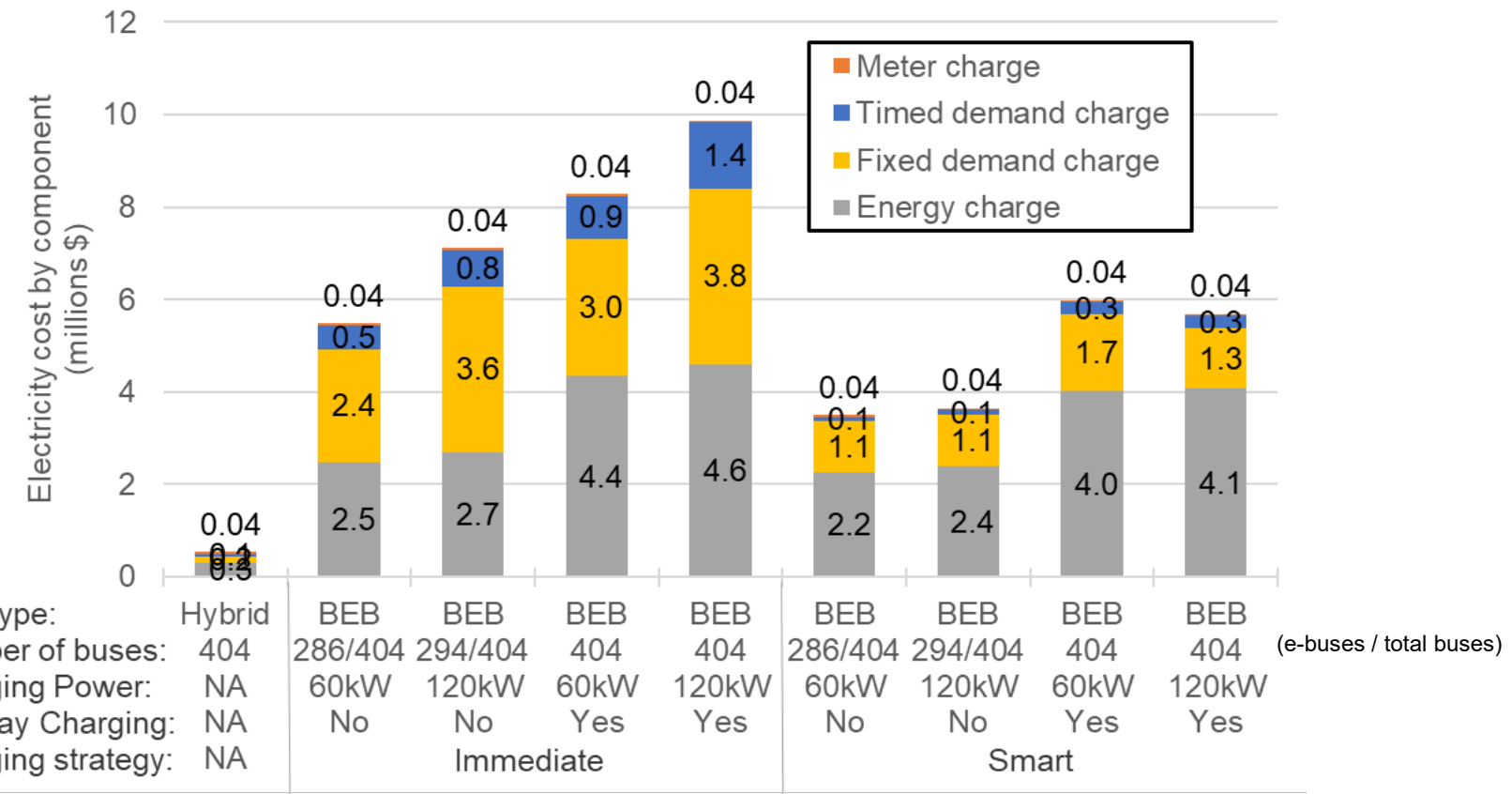

Figure 10. Total year-one electricity cost breakdown 


\subsection{Charger to Bus Ratio}

As the number of electric buses in the fleet increases, there is an opportunity to share chargers - granted that an appropriate strategy is in place to plug and unplug buses, as necessary. That means that you do not have to install a charger for every bus and can reduce your costs associated with charging. Figure 11 shows the maximum number of chargers used at any point during the year across all three bus yards for immediate and smart charging.

Not surprisingly, higher power charging reduces the number of required chargers and immediate charging requires a higher number of chargers than smart charging. The fraction of chargers to buses for immediate charging ranges from $44 \%-69 \%$ and for smart charging $26 \%-41 \%$. A $40 \%$ charger to bus fraction means that 2.5 buses could share 1 charger.

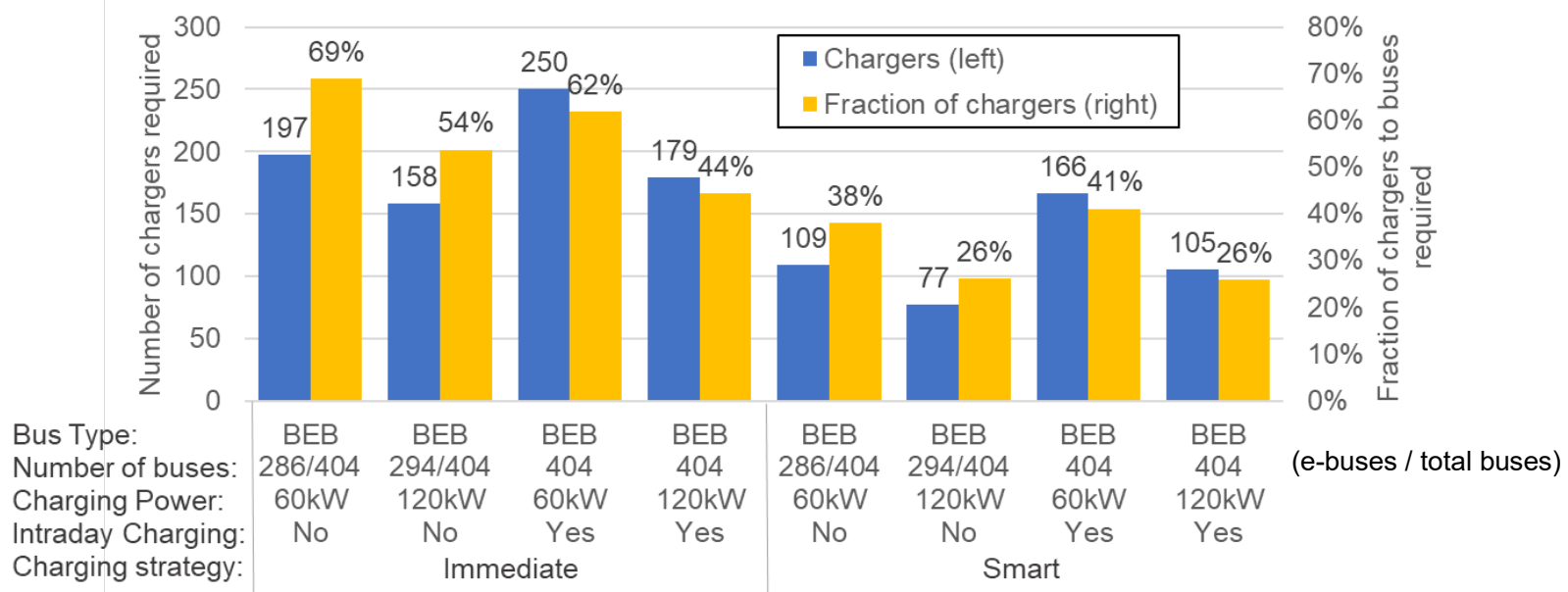

Figure 11. Comparison of the number of chargers required for each scenario

\subsection{Sensitivities}

Several sensitivity analyses were performed to understand the opportunity to install additional $\mathrm{PV}$ or storage to support electric vehicle operation.

\subsubsection{Impacts of Additional PV}

Each of VTA's bus yards already has PV installed, which can help offset electricity costs as well as increase the LCFS payment by increasing the carbon reductions of switching to battery electric buses, compared to just charging from the California grid.

The lifetime NPV cost impacts of doubling, tripling, and quadrupling the installed PV are shown in Figure 12. Using renewable energy to support smart charging of electric buses at Cerone results in a slight reduction in the total cost out to a tripling of PV capacity and then an increase in cost if any more is installed (e.g., quadrupling). This is expected as there is only so much charging that can occur during the afternoon due to trip scheduling and eventually the system reaches a saturation point. 


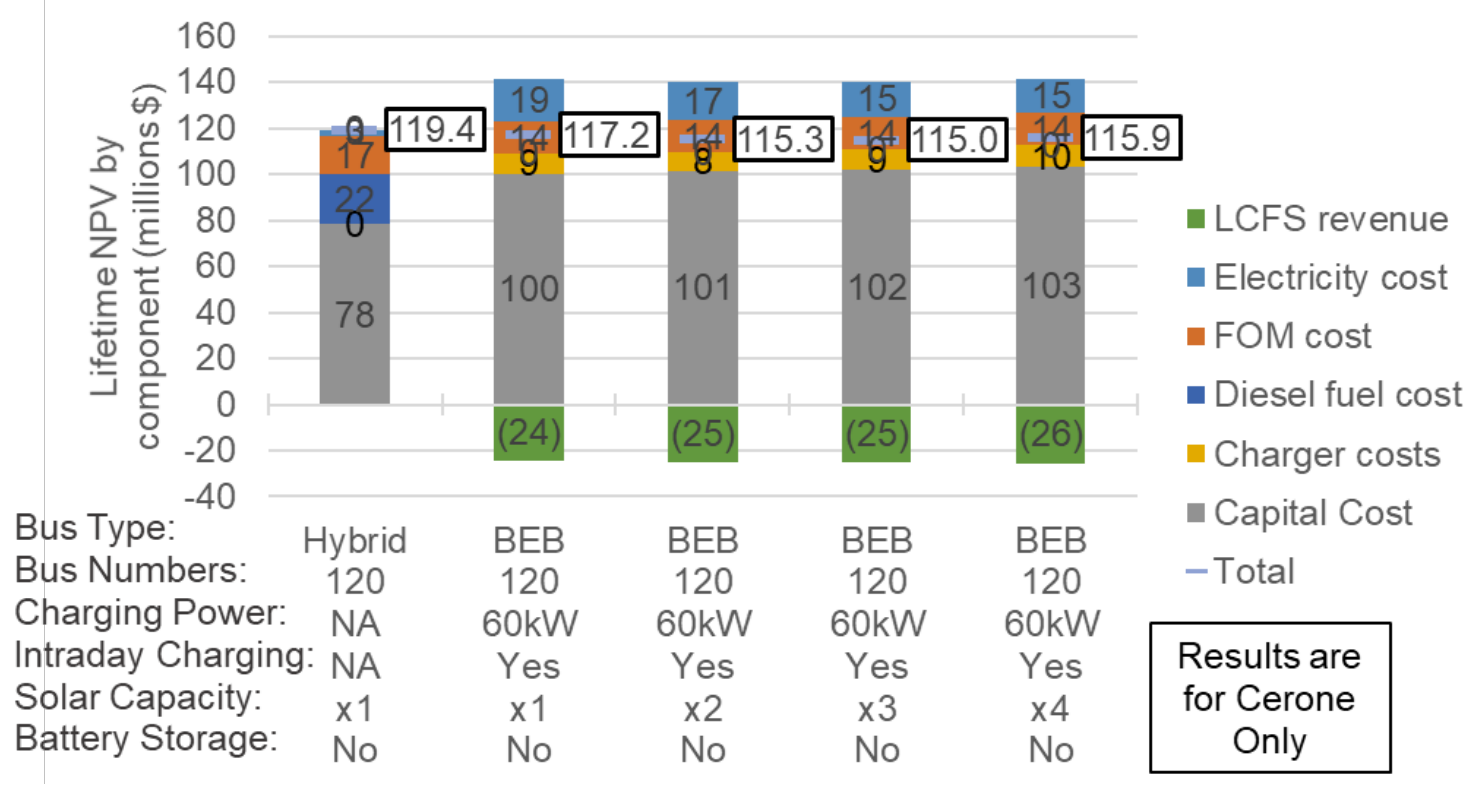

Figure 12. Lifetime NPV cost breakdown for Cerone with additional PV

We can see the saturation point more clearly by looking at the renewable production and curtailment or renewable export. In the current case, $41 \%$ of the generation is sold back to the grid using the net metering tariff. If the entire fleet of buses at Cerone is converted to electric, all the renewable production will be used. Doubling the on-site renewables results in $1 \%$ excess supply and tripling results in 5\% excess supply. Based on the equipment costs there is still a benefit to tripling the installation size; however, between tripling and quadrupling the value no longer outweighs the costs and the total system costs begin to rise.

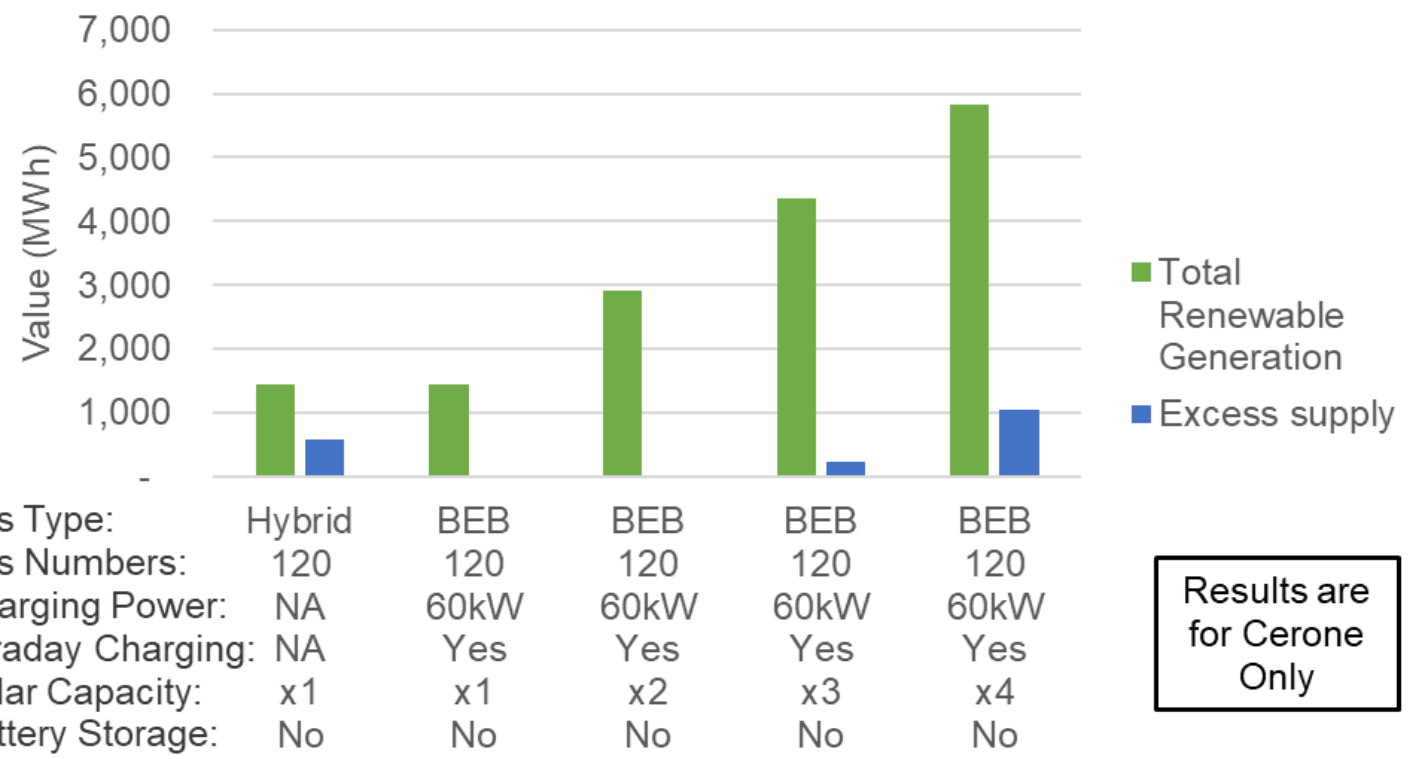

Figure 13. Renewable generation and excess supply for Cerone with additional PV 


\subsubsection{Impacts of Adding Storage}

Storage also presents an opportunity to provide benefits for site managers and the grid. For this analysis, we only consider behind-the-meter services-most notably retail utility rate management. In front of the meter services including wholesale services are not considered in this report. Considering the capital costs and round-trip efficiency penalty, there are tradeoffs between the benefits and costs for installing energy storage.

Battery sizes from $0.5 \mathrm{MW}$ to $4 \mathrm{MW}$ are considered and results are shown in Figure 14. The lowest cost option for Cerone is full electric bus implementation with smart charging without storage. Adding $0.5 \mathrm{MW}$ of storage will still result in a lower cost than the diesel-hybrid only scenario, but an increase compared to the case without storage. This is likely because smart charging has already reduced retail rate costs significantly and there is limited additional benefit that storage can provide. The same effect is seen as storage systems become larger. Lastly, we explored a case with increased PV capacity (i.e., four times the current installation) and a $4 \mathrm{MW}$ battery. The cost drops compared to the $4 \mathrm{MW}$ battery alone but does not reduce beyond the scenarios without batteries.

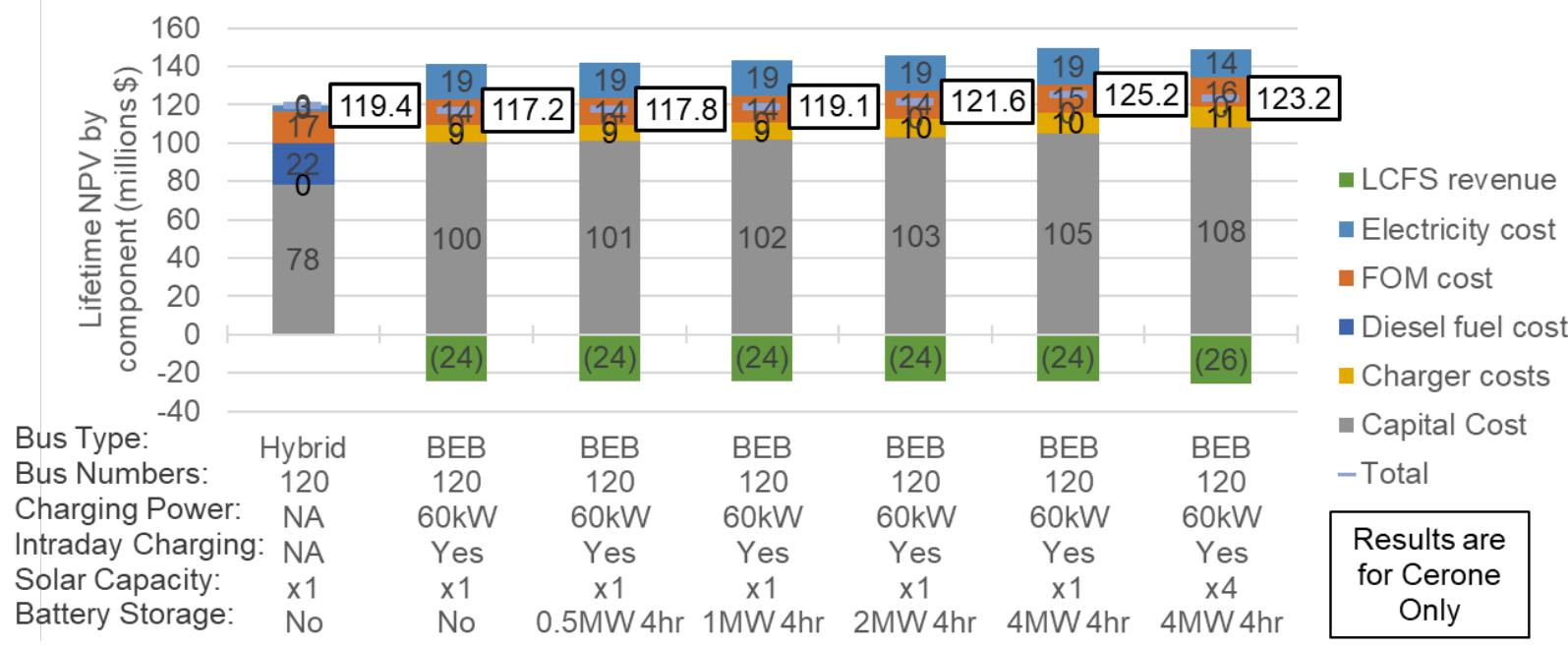

Figure 14. Lifetime NPV cost breakdown for Cerone with storage and PV

These results focus only on the arbitrage value of storage and do not consider the many other uses for batteries including local voltage and frequency support, wholesale market participation, emergency backup, etc. As a result, there are several factors in addition to what is presented here that must be considered when deciding to install batteries. 


\section{Conclusions}

This study endeavors to characterize the electrification potential of VTA's bus fleet under a variety of conditions and provide quantitative feedback to aid in decision making. This is done by exploring the ability of depot charging to meet electrification needs and also exploring the benefits and drawbacks of five methods for improving further improving electrification potential beyond depot charging alone including (1) increase charger power, (2) purchase of larger vehicle batteries, (3) en-route charging, (4) purchasing additional buses and swapping them to enable the existing routes/blocks to be met, and (5) route/block redesign. This study finds that VTA is likely able to electrify all its transit bus fleet trips by implementing a combination of the above strategies. Relying on only depot charging, VTA can electrify around $70 \%$ of its bus fleet trips can be replaced with typical BEBs. ${ }^{6}$

We developed a strategy to enable full fleet electrification by increasing charger power or allowing intraday charging as a proxy for the options just mentioned. Intraday charging can be done with en-route charging, bus swapping, or route/block redesign. This method allows us to develop an understanding of the impacts of full fleet electrification and can help understand the trade-offs when selecting the preferred method(s) to increase electrification.

Two charging strategies are examined. Immediate charging, when the bus is charged as soon as it arrives, and smart charging, which uses a controller to determine the best times to charge to achieve the lowest operating cost. Smart charging is effective at reducing the peak power consumption, which can be reduced by between $31 \%$ and $65 \%$ compared to immediate charging. This can reduce the required electric utility service that must be acquired by the site and will reduce the associated costs.

The total lifetime NPV costs for different scenarios were presented in Figure 7. Scenarios are separated into three sections. The first stacked bar on the left is the base case (business-as-usual) where all buses are diesel hybrids, the next four bars include partial and full fleet electrification utilizing only immediate charging, and the last four bars include partial and full fleet electrification utilizing smart charging. The results show that smart charging scenarios are within $\pm 4 \%$ of the lifetime NPV cost of the diesel-hybrid only (business-as-usual) scenario. The scenarios with full fleet electrification (i.e., including intraday charging) are 4\% lower cost and those with partial fleet electrification (i.e., without intraday charging) are $2 \%-3 \%$ higher. However, it is important to note that the intraday charging scenarios do not include any additional costs for the equipment necessary to achieve intraday charging (e.g., additional chargers, larger batteries, new route design). Additionally, it is worth noting that the LCFS credit received for implementing electric buses is essential to achieving the aforementioned results.

Additionally, smart charging is essential to lowering the lifetime NPV cost. While several studies have shown how the operating costs compare between conventional buses and BEBs-often for single vehicles - this report calculates the lifetime NPV costs including capital investment for the entire fleet. Given the cost and operating assumptions and the location in California, findings show that the smart charging scenarios are within $4 \%$ of the lifetime NPV cost as compared to the diesel-hybrid only scenario. The scenarios with full fleet electrification (i.e., including

\footnotetext{
${ }^{6}$ This assumes BEBs with typical levels of storage (i.e., 40' bus with $350 \mathrm{kWh}$ usable, 60 ' bus with $550 \mathrm{kWh}$ usable).
} 
intraday charging) are $4 \%$ lower cost and those with partial fleet electrification (i.e., without intraday charging) are $2 \%-3 \%$ higher. It is important to remember that the intraday charging scenarios do not include any additional costs to allow for additional charging to meet the routes. Options to achieve this increased electrification potential were discussed in detail in Section 3.2. Given these options, there are many ways to enable the full fleet to electrify but this will require additional investment in equipment and technology (e.g., en-route charging, larger batteries).

Compared to the diesel-hybrid scenario, BEB scenarios have lower operation costs and generally higher capital costs. Cost reductions in BEBs, charging infrastructure, and installation can all improve the results and should continue to be a priority. Interestingly, installing $120 \mathrm{~kW}$ chargers increases the flexibility of meeting charging demand and lowers the electricity cost but, given our assumptions, does not provide enough value to offset the added capital cost.

While this study tries to be as thorough as possible, there are a few things to remember that provide context for these results.

- The model assumes that buses always behave as anticipated (e.g., there are no breakdowns for either diesel-hybrids or BEBs). As a result, the fleet planners have perfect foresight into how buses can be charged. In reality, vehicle breakdowns occur, and mistakes are likely to be made with regard to charging or routing that will affect the cost of operation (e.g., electricity and diesel demand) or the number of buses required to meet the driving needs.

- All the scenarios with intraday charging include depot chargers but do not include any additional cost to enable the charging outside of the depot.

- It is assumed for this study that buses can rapidly begin charging at the end of the day. For VTA, buses arrive at a yard, enter a queue, and are cleaned before going to the charging station. The cleaning is done centrally so it is difficult to send buses directly to the charger and then clean them; however, it is feasible to create a process at VTA that would allow for quickly moving the buses to the charging stations. This may involve some costs (e.g., mobile cleaning) or other strategies, but is possible.

- The cost estimate does not include any electrical infrastructure upgrade costs. Infrastructure upgrades are triggered by an increase in the level of demand at a given facility. In order to enable higher level of demand, the utility will need to understand the impact on the surrounding grid. If there are costs for installing additional equipment to the facility or an affected neighbor's facility someone needs to pay these costs. It is possible that a utility will not charge the customer and roll them into the general rates, but it is also possible that all upgrades are the responsibility of the facility that requests the service upgrade. That means the cost could be zero dollars or millions of dollars. That can dramatically change the economics of a project and needs to be resolved with utilities. Right now, we do not have any estimates from PG\&E to upgrade service for VTA's bus yards, so we have not included any costs for these upgrades. 


\section{References}

Denholm, P., J. Eichman, and R. Margolis. 2017. Evaluating the Technical and Economic Performance of PV Plus Storage Power Plants. NREL/TP-6A20-68737. Golden, CO: National Renewable Energy Laboratory. https://www.nrel.gov/docs/fy17osti/68737.pdf.

Eichman, J., and F. Flores-Espino. 2016. California Power-to-Gas and Power-to-Hydrogen Near-Term Business Case Evaluation. NREL/TP-5400-67384. Golden, CO: National Renewable Energy Laboratory.

Eichman, J., M. Koleva, O. J. Guerra, O. J., and B. McLaughlin. 2020. Optimizing an Integrated Renewable-Electrolysis System. NREL/TP-5400-75635. Golden, CO: National Renewable Energy Laboratory. https://www.nrel.gov/docs/fy20osti/75635.pdf.

Eichman, J., A. Townsend, and M. Melaina. 2016. Economic Assessment of Hydrogen Technologies Participating in California Electricity Markets. NREL/TP-5400-65856. Golden, CO: National Renewable Energy Laboratory. http://www.nrel.gov/docs/fy16osti/65856.pdf.

Eudy, L., and M. Jeffers. 2018. Zero-Emission Bus Evaluation Results: King County Metro Battery Electric Buses. National Renewable Energy Laboratory and U.S. Department of Transportation Federal Transit Administration. https://www.transit.dot.gov/sites/fta.dot.gov/files/docs/research-innovation/115086/zeroemission-bus-evaluation-results-king-county-metro-battery-electric-buses-fta-report-no0118.pdf.

Eudy, L., R. Prohaska, K. Kelly, and M. Post. 2016. Foothill Transit Battery Electric Bus Demonstration Results. Golden, CO: National Renewable Energy Laboratory. https://www.nrel.gov/docs/fy16osti/65274.pdf.

Muratori, M., E. Kontou, and J. Eichman. 2019. "Electricity rates for electric vehicle direct current fast charging in the United States." Renewable and Sustainable Energy Reviews 113: 109235. https://doi.org/10.1016/j.rser.2019.06.042.

National Academies of Sciences, Engineering, and Medicine. 2018. Battery Electric Buses State of the Practice. Washington D.C.: The National Academies Press.

https://doi.org/10.17226/25061.

NREL 2019 Annual Technology Baseline. 2019. Golden, CO: National Renewable Energy Laboratory. https://atb.nrel.gov/electricity/2019.

Title 13. 2019. California Code of Regulations (CCR), sections 2023 and 2023.1-2023.11. https://oal.ca.gov/publications/ccr/. 